\title{
IRREDUTIBILIDADE E CONSTITUIÇÃO DIALÉTICA DA VIDA ÉTICA NO JOVEM HEGEL
}

Irreducibility and dialectical constitution of ethical life in young Hegel

Carlos Roberto Drawin *
Jacqueline de Oliveira Moreira **

Resumo: $\mathrm{O}$ nosso artigo tem como objetivo mostrar o caráter originário da vida ética no pensamento hegeliano, isto é, a exigência de pensá-la como irredutível à sua gênese empírica, quer na perspectiva do naturalismo, quer na do individualismo. Com tal propósito tomamos como foco de nossa análise o manuscrito de 1803-1804 que recebeu posteriormente o título de "Sistema de eticidade" ressaltando como a sua constituição dialética implica em ruptura com relação ao pensamento ético e político modernos e, desse modo, oferece fecunda contribuição para a discussão filosófica contemporânea. Embora sem avançarmos em direção da obra de maturidade do filósofo e permanecendo numa base textual bastante restrita, acreditamos que nela já podemos discernir alguns elementos para a crítica de uma abordagem materialista da ética.

Palavras-chave: Eticidade. Dialética. Ontologia. Intuição. Conceito.

Abstract: This article aims to show Hegel's original view of ethical life, that is, one that must be thought of as irreducible to its empirical genesis, in the perspective of naturalism and of individualism. With this purpose, we focus our analysis on the manuscript of 1803-1804, which later received the title of

\footnotetext{
* Doutor em Filosofia. Professor aposentado do Departamento de Filosofia da UFMG e Professor Titular da Faculdade Jesuíta de Filosofia e Teologia (FAJE). Artigo recebido em 17/08/2019 e aprovado para publicação em 03/10/2019.

** Mestre em Filosofia. Doutora em Psicologia. Professora do Programa de Pós-Graduação em Psicologia da Pontifícia Universidade católica de Minas Gerais. Bolsista produtividade do $\mathrm{CNPq}$.
} 
"Ethics System". We emphasize how its dialectical constitution implies a rupture with modern ethical and political thought and, therefore, offers a fruitful contribution to contemporary philosophical discussion. Although we do not discuss the philosopher's mature work and remain on a very restricted textual basis, we believe that we can already discern some elements for the critique of a materialist approach to ethics.

Keywords: Ethics. Dialectics. Ontology. Intuition. Concept.

pós a morte de Hegel a sua autoridade filosófica e a veneração ao
seu pensamento declinaram rapidamente. Apesar do seu prestígio
intelectual, consagrado com sua nomeação para a cátedra de Berlim, a sua posição política sempre foi objeto de controvérsia. Desde seus primeiros escritos ele avaliou com severidade a situação alemã caracterizada pela cisão entre o rigorismo da ética do dever e a fragilidade das instituições políticas efetivas. Após as guerras napoleônicas ele se empenhou em construir uma concepção científica do Estado, ou seja, da efetividade política em suas estruturas universais, mas sem jamais ceder ao nacionalismo alemão ou se inclinar à exaltação patriótica do Estado Prussiano. De qualquer forma ele foi duramente atacado de todos os lados, tanto por tradicionalistas, quanto por liberais e socialistas. ${ }^{1}$ Surpreendentemente a sua presença persistiu justamente na inversão crítica de sua intenção sistemática. Os seus herdeiros da chamada esquerda hegeliana disputaram o seu espólio para dele retirar o que lhes convinha em sua luta contra a religião e o Estado.

A desconfiança das autoridades em relação ao seu pensamento político recrudesceu após 1840 com a ascensão de Frederico Guilherme IV ao trono prussiano. Schelling e o jurista e teórico da Restauração Julius Stahl foram chamados para as cátedras de Filosofia e Direito da Universidade de Berlim. Em tal contexto, com o recrudescimento da censura e da vigilância policial, torna-se compreensível o ataque da esquerda hegeliana à "Filosofia do Direito", apesar dos críticos, no calor das polêmicas, nem sempre perceberem o difícil entrançamento da exposição do filósofo. Em 1842, Arnold Ruge publica o artigo "A filosofia do direito de Hegel e a política de nosso tempo" e nele fustiga a filosofia hegeliana por sua suposta clausura teórica e abstrata visando enfatizar como ele foi incapaz de pensar as consequências políticas de sua definição do Estado como "efetividade da ideia ética". Para esses representantes da chamada "esquerda", urgia combater a suposta confusão entre realidade e ideia, pois os novos tempos

${ }^{1}$ LÉCRIVAIN, André. Hegel et l'éthicité. Commentaire de la troisième partie des "Principes de la philosophie du droit". Paris: J. Vrin, 2001, p. 13-17. 
exigiam não o mero cultivo e sim a realização da filosofia por meio da transposição da especulação para a práxis. $^{2}$

No ano seguinte e numa perspectiva semelhante Marx se debruça em percuciente estudo da terceira seção da última parte da "Filosofia do Direito" dedicada à eticidade. Também ele mostra como se dá a inversão idealista ou abstrata entre a democracia representada pela "sociedade civil" (bürgerliche Gesellschaft) e o Estado: "Hegel parte do Estado e faz do homem o Estado subjetivado; a democracia parte do homem e faz do Estado o homem objetivado. Do mesmo modo que a religião não cria o homem, mas o homem cria a religião, assim também não é a constituição que cria o povo, mas o povo a constituição". ${ }^{3} \mathrm{~A}$ influência de Feuerbach aqui é inequívoca: a ilusão especulativa consiste em inverter a relação entre "sujeito" e "predicado", de maneira a transformar o homem em "Estado subjetivado" (zum versubjektivierten Staat) ao invés de compreender o Estado como "homem objetivado" (zum verobjektivierten Menschen). Com isso Marx pretendia liberar o potencial crítico da teoria da sociedade civil retirando a capa metafísica que a recobria, pois esta ocultava justamente a dura realidade do conflito social na penumbra da necessidade racional. Nada obstante, a severa posição adotada por Marx jamais desvalorizou a aguda compreensão hegeliana das exigências impostas para se alcançar uma concepção moderna da vida social e política.

Lastimavelmente, durante longo tempo, no rastro da ascensão e da influência mundial do marxismo, a teoria social e política hegeliana foi objeto de um sem número de acusações e equívocos fáceis, o mais grosseiro dos quais foi considerá-lo como mero ideólogo de um estado alheio à dinâmica histórica da sociedade, acusação feita com o intuito de considerá-lo como mero apologista da situação política efetivamente existente. ${ }^{4}$

O desejo de sistematizar e difundir a obra de Marx, já nítido em Engels em obras mais extensas e elaboradas como "O anti-Dühring" (1878) ou mesmo de fácil divulgação como "Do socialismo utópico ao socialismo científico" (1880-1882), acabou por estimular uma leitura simplista e linear da história, divorciada da complexidade inerente à lógica dialética de " $\mathrm{O}$

\footnotetext{
${ }^{2}$ ROSSI, Mario. La génesis del materialismo histórico. 1. La isquierda hegeliana. Madrid: Alberto Corazón Editor, 1971, p. 126-136. A consideração da filosofia de Hegel como uma "acomodação reacionária" ao Estado Prussiano não se inicia com Ruge, apesar de sua importância para a formação da "esquerda". Em algumas primeiras recensões da "Filosofia do Direito" já era feita a mesma censura e ele era acusado por sua "divinização idólatra do Estado". Cf. OTTMAN, Henning. Individuum und Gemeinschaft bei Hegel. Bd. I: Hegel im Spiegel der Interpretationen. Berlin-New York: Walter de Gruyter, 1977. p. 35. Ver "Nota 11" abaixo.

${ }^{3}$ MARX, Karl. Crítica da filosofia do direito de Hegel. Tradução Rubens Enderle e Leonardo de Deus. São Paulo: Boitempo Editorial, 2010, P. 50. IDEM. “Zur Kritik der Hegelschen Rechtsphilosophie". In: MARX, Karl und ENGELS, Friedrich. Werke. Bd. 1. Berlin: Dietz Verlag, 1964. p. 231.

${ }^{4}$ WOOD, Allen W. "Hegel e o marxismo". In: BEISER, Frederick C. Hegel. São Paulo: Ideias \& Letras, 2014. p. 481-515.
} 
capital". No contexto da Segunda Internacional coube a Karl Kautsky a tarefa de descartar a obra de Hegel, sem conhecê-la. A sua influência não pode ser minimizada, ao menos no contexto da extensa difusão do marxismo, pois, afinal, ele era o mais importante representante do socialismo internacional e da social-democracia alemã. Numa carta enviada a Engels ele reafirma o seu propósito de "popularizar o saber" e "esclarecer o operário" com pretensão de elevá-lo ao nível da ciência. ${ }^{5} \mathrm{Com}$ tal intenção ele concebia o marxismo, em contraposição à visão mais matizada de Engels, como uma teoria da história em continuidade com a evolução natural e, para isso, não temeu adotar uma perspectiva decisivamente determinista e economicista. Significativamente ele afirmou: "Marx e Engels partiram de Hegel, eu parti de Darwin". ${ }^{6}$

Contra tal tendência o próprio Lênin se insurgiu ao aproximar a "Ciência da lógica" de Hegel e o "O capital" de Marx, apostrofando aqueles que simplesmente desconsideravam a envergadura lógica do idealismo como adeptos "do ponto de vista do materialismo grosseiro, simples, metafísico...". Apesar de Lênin desconhecer o significado ontológico próprio da dialética ao transpô-la para o domínio do materialismo e confundi-la com um simples método. Para tanto ele recorreu à metáfora marxiana do "núcleo racional" e da "casca mística" da dialética e utilizou em sua leitura o princípio seletivo segundo o qual: "as passagens "ruins" e idealistas são anuladas, as "boas", onde o materialismo se mostra transparente, são ressaltadas". ${ }^{8}$ Seja como for, a sua opinião é significativa, porque ela testemunha o quanto o esforço de redescobrir o autêntico pensamento marxiano não poucas vezes esteve vinculado à investigação de suas raízes filosóficas hegelianas, mesmo quando a aproximação foi feita de modo equivocado. ${ }^{9}$

O mesmo ocorreu com o advento do marxismo ocidental nos anos vinte do século passado e assim testemunham as publicações de duas de suas obras inaugurais, ambas de 1923: "História e consciência de classe" de Georg Lukács e "Marxismo e filosofia" de Karl Korsch. ${ }^{10}$ Nelas a dialética hegeliana

\footnotetext{
5 SALVADORI, Massimo L. "Kautsky entre ortodoxia e revisionismo". In: HOBSBAWM, Eric et al. (Org.) História do marxismo II: o marxismo na época da Segunda Internacional. Rio de janeiro: Paz e terra, 1982. p. 303.

${ }^{6}$ JONES, Gareth Stedman. "Retrato de Engels". In: HOBSBAWN, Eric et al. (Org.). História do marxismo I: o marxismo no tempo de Marx. Rio de janeiro: Paz e terra, 1979, p. 382-383.

${ }^{7}$ LÊNIN, Vladimir Ilitch. Cadernos filosóficos: Hegel. São Paulo: Boitempo, 2018, p. 336.

${ }^{8}$ ARNDT, Andreas. "Lenin liest Hegel". Hegel-Studien. Beiheft 55. Hamburg: Felix Meiner Verlag, 2011. p. 281.

9 PUNTEL, L. Bruno. “ A 'Ciência da lógica' de Hegel e a Dialética Materialista: uma nova visão de um antigo problema". Síntese, v.II, n. 5 (outubro-dezembro, 1975), p. 3-36.

${ }^{10}$ Korsch era leninista e atacava Kautsky e Bernstein, lamentando o retrocesso do pensamento com o "regresso a Kant" após a morte de Hegel. Cf. KORSCH, Karl. Marxismo e filosofia. Porto: Edições Afrontamento, 1977. p. 72. Para Korsch e Lukács, ver: JEFFRIES, Stuart. Grande Hotel Abismo: a Escola de Frankfurt e seus personagens. São Paulo: Companhia das Letras, 2018, p. 89 ss.
} 
foi reavaliada em contraposição à aproximação, promovida pelos teóricos da Segunda Internacional, do materialismo histórico com as ciências da natureza, o cientificismo e a filosofia empiriocriticista. Apesar disso, o clima ideológico menos adverso não foi suficiente para a autêntica redescoberta da força renovadora do pensamento político hegeliano, tarefa cumprida apenas pela Hegelforschung em seu empenho de reconstituição textual, como aquele empreendido por Karl- Heinz Ilting em sua monumental edição das "Lições sobre a filosofia do direito" (1819-1831) acompanhada de revisão crítica de suas interpretações. ${ }^{11}$

Se a redescoberta da dialética hegeliana no contexto do marxismo ocidental deveu-se, em grande parte, à crítica tanto do naturalismo, quanto da pretensão de buscar uma fundamentação científica externa e positiva para o materialismo histórico, então talvez aí resida o motivo da incompreensão básica do pensamento político hegeliano. Ou seja, a incompreensão não resultou apenas de uma distorção circunstancial vinculada a alguns momentos da história do marxismo e sim da assunção de um pressuposto filosófico forte já presente na análise de Marx da filosofia hegeliana do

\footnotetext{
${ }^{11}$ A investigação filológica de Ilting, feita nas décadas de 1970 e 1980 não pode ser minimizada e diversos outros trabalhos editoriais se seguiram à sua edição crítica. No entanto, o rigor filológico não exclui a adoção de uma determinada postura hermenêutica. Ilting procurou mostrar que a posição política hegeliana sofre uma inflexão conservadora entre 1817, quando escreveu sobre a situação de Würtemberg (Ständeschrift) e a "Filosofia do Direito" de 1820 em decorrência de diversos acontecimentos políticos na Alemanha como os "Decretos de Karlsbad" de agosto de 1819 os quais levaram a uma política repressiva. Assim, afirma Ilting, a filosofia política hegeliana, sobretudo nas "Grundlinien", tende à "acomodação" com a realidade, inclusive com a situação contemporânea do Estado Prussiano. Cf. ILTING, K- H. "Einleitung". In: HEGEL, G. W. F. Vorlesungen über Rechtsphilosophie 1818-1831. Erster Band. Naturrecht und Staatswissenschaft. Vorlesung 1818-1819 nach der Nachschrift Carl Gustav Homeyers. Edition und Kommentar in sechs Bänden von Karl-Heinz Ilting. Stuttgart: Friedrich Frommann Verlag, 1973. p. 32-43. Cf. VAZ, Henrique C. de Lima. “Recensão de 'G.W.F. Hegel. Vorlesungen über Rechtsphilosophie (1819-1931). Edition und Kommentar von Karl-Heinz Ilting'". Síntese, v. II, n. 4, p. 19-24, julho-setembro 1975. IDEM. “Nota bibliográfica: a filosofia política de Hegel". Síntese, v. VIII, n. 22, p. 113-122, maio-agosto 1981. Compreende-se, então, a virulência crítica dos representantes da "esquerda hegeliana". Mas, apesar da opinião de Ilting, a Hegelforschung inaugura as condições para que a discussão seja colocada em outro patamar. O nosso texto, como afirmado diversas vezes, busca apenas alguns subsídios para uma hipótese hermenêutica geral. Para a discussão da interpretação de Ilting, ver: PIRES, Edmundo Balsemão. Povo, eticidade e razão. Contributos para o estudo da filosofia política de Hegel. Vol. I. Lisboa: Imprensa Nacional - Casa da Moeda, 2006. p. 282-299. Apesar das críticas liberais e marxistas observa Henrique Vaz: "a atualidade do pensamento político de Hegel permanece, no entanto, como exigência indeclinável da busca de um novo horizonte de universalidade ética que permita pensar a prática da liberdade e a garantia dos direitos nas sociedades políticas modernas, ameaçadas pelo crescimento desmesurado da Razão instrumental ou das tecnoburocracias..." Cf. VAZ, Henrique C. de Lima. "Sociedade civil e Estado em Hegel". Síntese, v. VII, n. 19, p. 27. Para uma meditação profunda do problema em questão, ver: VAZ, Henrique C. de Lima. "Ética e Direito". In: Idem. Escritos de filosofia II. Ética e cultura. São Paulo: Edições Loyola, 1988, p. 135-180. Sobretudo p. 161-180. Cf. VAZ, Henrique C. de Lima. “Recensão de 'G.W.F. Hegel. Vorlesungen über Rechtsphilosophie (1819-1931). Edition und Kommentar von Karl-Heinz Ilting'". Síntese, v. II, n. 4, p. 19-24, julho-setembro 1975. IDEM. "Nota bibliográfica: a filosofia política de Hegel". Síntese, v. VIII, n. 22, p. 113-122, maio-agosto 1981.
} 
direito quando ele ainda estava sob o influxo da antropologia naturalista feuerbachiana. Ora, como se sabe, a rejeição deste tipo de antropologia encontra-se no ponto de partida do pensamento político hegeliano, por isso é essencial compreender o seu significado filosófico, ou seja, o estatuto especulativo de sua "sistematização racional do campo ético-político". ${ }^{12}$

Obviamente, há de se ressaltar, Marx não é um "intérprete" de Hegel a ser corrigido por qualquer tipo de pesquisa acadêmica. Ao contrário, ele é um pensador original e eminente cuja obra inaugura a riquíssima vertente da teoria social crítica e, por conseguinte, ela possui autonomia e deve ser lida conforme a ordem interna de suas razões. Porém, se no apogeu do marxismo a obra de Hegel foi muitas vezes lida pelos olhos de Marx, então agora, o confronto com pensamento hegeliano pode proporcionar à leitura de Marx, numa época que não cessa de proclamar a sua morte definitiva, preciosos estímulos teóricos. ${ }^{13}$

Nos anos noventa do século passado, após o desmoronamento do socialismo real seguiu-se efervescente discussão em torno da pertinência e extensão dos Direitos Humanos. Na esteira da insatisfação com relação às teorias políticas de cunho liberal ressurgiu a fecundidade de algumas intuições hegelianas. Dois eminentes estudiosos do filósofo alemão publicaram textos importantes sobre o reconhecimento como ideal normativo: Axel Honneth em 1992, com "Luta por reconhecimento. A gramática moral dos conflitos sociais" e Charles Taylor em 1994 com "A política do reconhecimento ${ }^{14}$. Na primeira parte do livro de Honneth, intitulada "Presentificação histórica: a ideia original de Hegel", o autor retoma as ideias de intersubjetividade e reconhecimento desenvolvidas pelo filósofo em seu período de Iena.

Afinal, já nos textos daquele período ele havia deixado para trás o individualismo subjacente às teorias contratualistas e a abordagem hobbesiana que privilegiava a luta por autoconservação e se encaminhava para a concepção de eticidade (Sittlichkeit) cujo florescimento maduro ocorreria na terceira parte de suas "Linhas fundamentais da filosofia do direito". Nessa época de Iena ele tomava distância crítica tanto do naturalismo, associado à ideia do homem como indivíduo possessivo e constitutivamente egoísta, quanto do subjetivismo moral, impotente para pensar a substância da vida social e a objetividade do direito. Posteriormente, nas lições do semestre de inverno de 1818 ele afirma no $\S 3^{\circ}$ da "Introdução" o pressuposto indeclinável de sua exposição: "o princípio do direito não repousa na natureza ...nem na natureza subjetiva do homem ... isto é, na esfera das necessidades (Sphäre der

\footnotetext{
${ }_{12}$ BOURGEOIS, Bernard. Le droit naturel de Hegel (1802-1803). Commentaire. Paris: J. Vrin, 1986, p.7.

${ }^{13}$ WOOD, op. cit. p.486.

${ }^{14}$ ROSAS, João Cardoso, GONZÁLEZ, Iñigo e THALER, Mathias. "Filosofia política". In: GALVÃO, Pedro. Filosofia: uma introdução por disciplinas. Lisboa: Edições 70, 2013, p. 188-206.
} 
Bedürfnisse), pulsões e inclinações... a esfera do direito é a esfera da liberdade ...na medida em que a liberdade existe e se exterioriza..."15 $\mathrm{O}$ mesmo se dá no $§ 142$ de suas "Linhas fundamentais da Filosofia do Direito", ali ele definiu da mesma maneira a eticidade identificando-a com a ideia da liberdade, a qual não pode ser confundida com o puro dever da consciência e muito menos com o arbítrio individualista, porque nela trata-se do "Bem vivente" a ser atualizado ou mediado na efetividade concreta da vida social. ${ }^{16}$

O nosso propósito, ao refazermos brevemente tal problemática certamente não é o de contrapor Hegel a Marx e muito menos expor ou avaliar a retomada por Honneth do Hegel de Iena. Nem mesmo visamos abordar o conceito de eticidade em toda sua complexa abrangência e em sua formulação madura. Ao contrário, limitamo-nos a apresentar um exercício de leitura de um texto ainda pouco conhecido entre nós, o "Sistema de eticidade". Talvez seja pertinente fazê-lo quer por sua escassa divulgação, quer por sua obscuridade intrínseca, embora o enfoque analítico não pretenda sustentar a impossível distância da neutralidade, porque a nossa leitura se orienta por uma hipótese de fundo de grande generalidade segundo a qual a vida ética possui um caráter originário e irredutível e torna-se um completo enigma quando retirada do horizonte de sua inteligibilidade ontológica e/ou metafísica. ${ }^{17}$

Com tal intuito dividimos o nosso texto em três partes: na primeira situamos o manuscrito de Hegel, escrito entre o outono e o inverno de 1802-1803, dando alguma atenção ao artigo contemporâneo sobre o Direito Natural; na segunda parte fazemos uma exposição resumida de algumas passagens fundamentais do argumento hegeliano desenvolvido no "Sistema de eticidade"; na terceira fazemos observações gerais e bastante livres acerca

${ }^{15}$ Cf. "Das Prinzip des Rechts liegt nicht in der Natur, ohnehin nicht in der äussern, auch nicht in der subjektiven Natur des Menschen, insofern nämlich sein Wille natürlich bestimmmt d.i. die Sphäre der Bedürfnisse, Triebe und Neigungen ist. Die Sphäre des Rechts ist die Sphäre der Freiheit, in welche $[\mathrm{r}]$ insofern die Freiheit sich äussert und sich Existenz gibt, die Natur zwar eintritt, aber als ein unselbstständiges". HEGEL, G. W. F. Vorlesungen über Rechtsphilosophie 1818-1831. Zweiter Band. Naturrecht und Staatswissenschaft. Vorlesung 18181819 nach der Nachschrift Carl Gustav Homeyers. Edition und Kommentar in sechs Bänden von Karl-Heinz Ilting. Stuttgart: Friedrich Frommann Verlag, 1973. p. 239.

${ }^{16}$ Cf. Linhas fundamentais da Filosofia do Direito ou Direito natural e Ciência do Estado em compêndio. São Leopoldo: Editora Unisinos; São Paulo: Edições Loyola, 2010. Tomamos como referência a tradução brasileira realizada por uma equipe de tradutores liderada pelo Prof. Dr. Pe. Paulo Meneses SJ. As nossas considerações estão baseadas na exposição já clássica feita por Denis Rosenfield acerca do conceito de eticidade. Ver ROSENFIELD, Denis Lerrer. Política e liberdade em Hegel. São Paulo: Brasiliense, 1983. p. 135-273. Esp. p. 135-141.

${ }^{17}$ Usamos a expressão "ontológica e/ou metafísica" para não entrarmos aqui na controvérsia acerca do estatuto da "Lógica": se seria uma ontologia ou uma metafísica de tipo neo-platônico. A discussão visa, na verdade, rejeitar a interpretação heideggeriana da "Lógica" como uma onto-teo-logia. Ver: PLANTY- BONJOUR, Guy. Le projet hégélien. Paris: J. Vrin, 1993. p. 172-177. Ver a respeito o comentário de: VIEILLARD-BARON, Jean-Louis. Hegel. Système et structures théologiques. Paris: Les Éditions Du Cerf, 2006. p. 11-12. 
não só da relevância atual, mas também do grande alcance filosófico do conceito de eticidade.

A vida humana é constituída, por definição, no e pelo convívio entre os homens. Quando se instaura a possibilidade da relação com o outro, fica em aberto o modo particular como esse relacionamento irá se efetivar. A modalidade mais comum da relação com o outro é a do conflito ou da luta mortal, quando o eu se aproxima do outro para escravizá-lo, usurpá-lo, reduzi-lo ao mesmo. Um desafio se impõe: como pensar a vida social e política de modo garantir o convívio razoavelmente ordenado entre os homens? Tal interrogação não deve ser tomada num sentido abstrato e sim como sendo o desafio dramático posto no limiar da modernidade pelo horizonte de esperança e incerteza aberto pela Revolução Francesa. Grosso modo também este é o desafio enfrentado por Hegel em seu texto "Sistema de eticidade".$^{18} \mathrm{O}$ manuscrito incompleto de Hegel foi publicado apenas em 1893 e sua localização cronológica foi objeto de larga discussão pelos estudiosos. Conforme a cronologia proposta por Heinz Kimmerle ele teria sido escrito em estreita vinculação com a primeira parte do curso sobre o direito natural ministrado no inverno 1802/1803 ou no mais tardar na primavera de $1803^{19}$. Tal localização parece mostrar que o "Sistema de eticidade" não antecipa o sistema da maturidade tal como foi exposto na "Enciclopédia das ciências filosóficas em compêndio" (1817; 1830), mas se situa num conjunto de textos, nos quais política e religião se entrecruzam numa concepção marcadamente influenciada por Schelling e criticamente distanciada das posições Kant e de Fichte. Os textos mais importantes deste conjunto são: o "Escrito sobre a diferença" (final de julho de 1801), "Relação do ceticismo com a filosofia" (fevereiro de 1802); "Fé e saber" (junho de 1802), "Sobre a relação da filosofia da natureza para com a filosofia em geral" (outono, 1802), "Sobre o tratamento científico do direito natural" (novembro de 1802). Não há como abordar todo esse conjunto de textos e nos restringimos a algumas poucas observações acerca do último texto mencionado

\footnotetext{
${ }^{18} \mathrm{O}$ manuscrito de Hegel está traduzido para o português: HEGEL, G.W.F. O sistema da vida ética. Tradução Artur Morão. Lisboa: Edições 70, 1991. Há também traduções para o francês e para o espanhol. Cf.: HEGEL, G.W.F. Système de la vie éthique. Traduit et presenté par Jacques Taminiaux. Paris: Payot, 1976 e HEGEL, G.W.F. El sistema de la eticidad. Edición e traducción por Dalmacio Negro Pavón y Luis González-Hontoria. Madrid: Editora Nacional, 1982. Seguimos aqui, cotejando com as traduções acima mencionadas, o texto alemão publicado em: Georg Wilhelm Friedrich Hegel. Frühe politische Systeme. Herausgegeben und kommentiert Von Gerhard Göhler. Frankfurt/M-Berlin-Wien: Verlag Ullstein, 1974. p. 15-102. Citado como "Sittlichkeit" seguido de página.

${ }^{19}$ KIMMERLE, Heinz. "Zur Chronologie von Hegels Jenaer Schriften". Hegel-Studien. Bd. 4, 1967, p. 153-154.
} 
O artigo de 1802-1803 intitulado "Sobre as maneiras científicas de tratar o direito natural", foi considerado por eminente estudioso francês como "obra germinal" de todo desenvolvimento posterior do filósofo em sua extraordinária força especulativa ${ }^{20} \cdot{ }^{21}$ Nele, como antes foi mencionado, Hegel deixa para trás o individualismo subjacente às teorias contratualistas com o seu fundamento hobbesiano de uma luta por autoconservação e se encaminha para a concepção de vida ética (Sittlichkeit) cujo florescimento maduro ocorreria na terceira parte de suas "Linhas fundamentais da filosofia do direito". O juízo de Bernard Bourgeois justifica-se plenamente, pois o chamado "Direito natural moderno", tal como foi elaborado entre 1600 e 1800, situa-se em sua forma metodológica e em seu conteúdo doutrinal no coração mesmo da modernidade. Após o desmoronamento da cristandade medieval, do impacto epistemológico da nova ciência da natureza e das lutas que engendraram a reivindicação do Estado Moderno de deter o monopólio do uso da violência, a teoria do direito natural responde pela autonomia da política frente à moral e à busca de fundamentação das normas jurídicas e políticas na ideia de natureza humana. Há diversas vertentes no jusnaturalismo moderno, Hegel, porém, procura apreender a fecunda novidade e o risco contidos em seu núcleo conceptual. O conceito de eticidade, endossando a ideia de liberdade como fonte de legitimidade da política, se distancia tanto do naturalismo, associado à ideia do homem como indivíduo possessivo e constitutivamente egoísta, quanto do subjetivismo moral, impotente para pensar a substância da vida social e a objetividade do direito. ${ }^{22}$

O título do artigo já contém um ponto programático essencial: com o êxito das ciências matemáticas e físicas ambas trilhando "a via segura da ciência", como Kant reconhece no prefácio à segunda edição da Crítica da razão pura, caberia à filosofia tão somente o lugar secundário da reflexão acerca do domínio exterior da ciência? Ou poderia ela ainda reivindicar a sua posição de independência em relação a qualquer saber que lhe fosse exterior, em outras palavras, reivindicar-se como fundamentação absoluta?

\footnotetext{
${ }^{20}$ BOURGEOIS, Bernard. Le droit naturel de Hegel (1802-1803). Commentaire. Paris: J. Vrin, 1986, p. 8.

${ }^{21}$ Seguimos aqui de perto a introdução do extraordinário comentário de Bernard Bourgeois sobre o direito natural de Hegel. $\mathrm{O}$ artigo de Hegel foi publicado no segundo volume do Kritisches Journal der Philosophie de 1802-1803. Há uma tradução brasileira: Sobre as maneiras científicas de tratar o direito natural. Tradução e apresentação de Agemir Bavaresco e Sérgio B. Christino. São Paulo: Edições Loyola, 2007. Salvo advertência em contrário a ela recorremos juntamente com o texto alemão publicado em: HEGEL, G.W. Frühe politische Systeme. Op. cit. p. 103-199. Citado como Naturrechtaufsatz seguido da página e de acordo com a tradução brasileira citada como Direito natural seguida de página.

${ }^{22}$ Cf. BALSEMÃO, Edmundo Pires. Povo, Eticidade e Razão - Contributos para o Estudo da Filosofia Política de Hegel. Lisboa: Imprensa Nacional - Casa da Moeda, 2006, p. 27-38. BOBBIO, Norberto e BOVERO, Michelangelo. Sociedade e Estado na filosofia política moderna. São Paulo: Editora Brasiliense, 1986, p. 13-100.
} 
Na primeira alternativa, e este seria o caso da filosofia kantiana da reflexão, o estatuto da filosofia ficaria indeterminado e sua dependência acabaria levando ao ceticismo, pois afinal de contas, nos depararíamos com a aporia da ciência fundada ter primazia sobre a ciência por princípio fundante. Ora, a filosofia não comporta tal tipo de dependência e, por isso, a ideia de filosofia como ciência verdadeira é o absoluto, isto é, ela permanece em sua liberdade e embora livre de toda determinidade "ela pode se refletir, nesta ciência determinada tão puramente quanto a vida absoluta se exprime em cada vivente..." ${ }^{23}$ A referência à "vida absoluta" não é arbitrária, pois nela encontramos a ressonância de seu posicionamento em relação à filosofia de sua época conforme ele já havia exposto em seu artigo de julho de 1801 sobre a diferença entre os sistemas de Fichte e Schelling. A noção de vida é a de uma atividade criativa e esta, como viu Kant, encontra-se justamente na constituição das categorias pelo Eu transcendental embora o filósofo de Königsberg tenha permanecido prisioneiro da concepção subjetivista assumida como corolário necessário da pressuposição dogmática da coisa-em-si. O projeto de Hegel, anunciado no prefácio de seu "escrito sobre a diferença" (Differenzschrift), ainda fortemente vinculado à filosofia da identidade de Schelling, consistia em fazer reviver a filosofia libertando-a dos compartimentos estanques do entendimento, suprimindo a sombra hipostasiada da coisa-em-si de modo a reencontrar o dinamismo vivo situado para além da relação extrínseca de sujeito e objeto e, desse modo, podendo substituí-la como inter-relação intrínseca de natureza e espírito. Ora, só se pode pensar tal relação intrínseca, dinâmica e viva se o fizermos à luz do absoluto concebido conforme a pressuposição, contrária à visão do senso comum (Popularphilosophie), segundo a qual cabe ao esforço racional orientar-se "em direção à consciência da identidade do finito e do infinito, ou seja, em direção ao saber e à verdade". ${ }^{24}$ A filosofia se propõe realizar no pensamento este reencontro da vida consigo mesma e este é o caminho do absoluto e, por isso, Hegel pôde afirmar logo no início do escrito sobre o direito natural a necessidade de identificar a ciência verdadeira com o absoluto e afastá-la da impureza (Ver-unreinigung) dos conceitos fixos. ${ }^{25}$

\footnotetext{
${ }^{23}$ Cf.: "aber von dieser Bestimmtheit bleibt die Idee selbst frei, und vermag sich in dieser bestimmten Wissenschaft so rein zu reflektieren, als das absolute Leben in jedem Lebendigen sich ausdrückt;" Naturrechtaufsatz, 105; Direito natural,36.

${ }^{24}$ Cf. HEGEL, G.W.F. "Differenz des Fichteschen und Schellingschen Systems der Philosophie". In: IDEM. Jenaer Kritische Schriften. Gesammelte Werke. Bd. 4. Herausgegeben Von BUCHNER, Hartmut und PÖGGELER, Otto. Hamburg: Felix Meiner Verlag, 1969, p. 92. Ver os esclarecedores comentários de Marcel Méry para a tradução francesa. G.W.F. HEGEL. Premières publications. Différence des systèmes philosophiques de Fichte et de Schelling - Foi et savoir. Traduction, introduction et notes par Marcel Méry. Paris: Éditions Ophys, 1964. p. 16-38. Sobre o "princípio de identidade" concebido por Schelling na "Exposição de meu sistema de filosofia" de 1801, ver: MARQUET, Jean-François. Liberté et existence. Étude sur la formation de la philosophie de Schelling. Paris: Gallimard, 1973. p. 207 ss.

${ }^{25}$ Cf. "weil das, wodurch sie wahrhafte Wissenschaft ist, das Absolute ist". Naturrechtaufsatz, 105 e 106; Direito natural, 36.
} 
Hegel tem em vista a reapropriação filosófica da teoria do direito natural e sendo a filosofia concebida como "ciência absoluta" ou "ciência da ideia absoluta", o jusnaturalismo moderno deve ser repensado sob a inspiração da tradição metafísica proveniente de Platão e Aristóteles. Nesse sentido é que se impõe a rejeição do empirismo, representado pelas teses de Hobbes e Locke acerca do estado de natureza e do formalismo, representado pelas teses de Kant e Fichte, acerca da oposição entre a razão prática e a realidade sensível. As primeiras "misturam a intuição e o conceito...enquanto a Ideia exige não as misturar, mas as reunir autenticamente, ou seja, as identificar", já as segundas se perdem na "universalidade vazia", na "absolutidade do sujeito", no "infinito formal". ${ }^{26}$

Por isso, diz Hegel em Naturrecht que ambas as abordagens são "modos inautênticos de tratar cientificamente do direito natural", cuja diferença consistiria no tratamento empírico a "mistura da intuição empírica e do universal" e no tratamento formal "uma oposição absoluta e uma universalidade absoluta" das quais só pode resultar "relações ou identidades relativas". ${ }^{27} \mathrm{O}$ empirismo converge "com o entendimento comum, que se mantém na mistura turva do que é em si e do que é passageiro" (...) e, assim, é incapaz de apreender a unidade, se perdendo "numa grande multidão de particularidades e de oposições...", o "caos do estado de natureza" é dispersão carente de "necessidade interior" e dele não pode emergir uma totalidade orgânica e dinâmica. ${ }^{28}$ Por outro lado, o formalismo não se perde na mistura das particularidades porque reconhece a exigência da identidade e aí reside a sua superioridade. No entanto, "no que se denomina razão prática, não há ...senão a conhecer a ideia formal da identidade do ideal e do real (...) mas aquela ideia não procede da diferença e o ideal não provém da realidade; pois, ainda que, nesta razão prática , o ideal e o real sejam idênticos, o real permanece, portanto, absolutamente oposto; este real é posto, essencialmente, fora da razão..." 29 Se, no caso do formalismo há separação entre o ideal e o real, o universal e o particular ou entre o dever moral e o indivíduo sensível, então é inevitável a imposição externa ou a coação (Zwang) da razão prática sobre o indivíduo, ou seja, da idealidade abstrata sobre a realidade concreta.

Descartando as alternativas do empirismo e do formalismo o direito natural pode ser colocado sobre o prisma da filosofia no sentido preliminarmente indicado na conclusão do Differenzschrift como orientação para a identidade do finito e do infinito. Pode-se falar em direito natural especulativo, porque nesta perspectiva o infinito não se põe abstratamente, mas se realiza na efetividade da vida ética, e esta pode ser designada como "vida

\footnotetext{
26 TAMINIAUX, Jacques. Naissance de la philosophie hégélienne de l'État. Commentaire et traduction de la Realphilosophie d'Iéna. Paris: Payot, 1984, p. 93-94.

${ }_{27}$ Cf. Naturrecht, 109-110; Direito Natural, p. 40

${ }^{28}$ Cf. Naturrecht, 115-116; Direito Natural, p. 46-47.

${ }^{29}$ Cf. Naturrecht, 126; Direito natural, p. 57.
} 
ética absoluta" (absolute Sittlichkeit) porque nela há uma relação interior entre a liberdade particular e a liberdade universal, uma relação não mais designada como "coação" (Zwang) e sim como "repressão" ou "sujeição" (Bezwingung). ${ }^{30}$ Aqui o termo deve ser compreendido como a primazia da totalidade ética sobre o domínio "prático real", seja em seu aspecto subjetivo enquanto "necessidades e gozos físicos", seja em seu aspecto objetivo enquanto "trabalho e posse". A "repressão" não deve ser confundida com uma aniquilação exercida em benefício de uma totalidade facilmente interpretada como algum tipo de totalitarismo e sim integração desses diversos aspectos negativamente mediatizada. Isto é, a integração não é imposta e nem emana de alguma harmonia pré-estabelecida. Por isso, diz Hegel, "a organização ética não pode, na realidade, conservar-se pura", porque não pode eliminar de si mesma a dimensão da necessidade e do trabalho, da posse e da propriedade. ${ }^{31}$ Neste ponto de sua exposição o filósofo está discutindo a concepção clássica da vida ética como contraponto da teoria moderna do direito natural, contudo a sua visão retrospectiva não se perde em nostalgia e a pólis grega não pode ser tomada como um modelo a ser seguido, mas deve ser apreendida em sua deriva histórica ou, antes, nós modernos somos instados a ler na dissolução de sua unidade substancial o destino (Schicksal) da civilização em seu significado metafísico. ${ }^{32}$ Destino especialmente visível com a emergência e afirmação modernas "do princípio de subjetividade (que) se entrelaça com a cisão ontológica entre sujeito e objeto", daí a inevitável violência de toda tentativa exteriormente imposta de coerção por parte de alguma totalidade artificial ou a vanidade ética de qualquer lógica sistêmica justificada em nome das "potências subterrâneas" (unterirdischen Mächten) da vida sensível e das necessidades materiais circunscritas pela esfera da economia. Talvez se possa dizer e Hegel mesmo o faz que a época moderna tenha relegado a tragédia ao passado e a tenha convertido em espetáculo cômico com a sua transfiguração em consciência-de-si. De qualquer modo, a tragédia grega certamente não é mais a de nossa modernidade, nela, porém, se instala a "tragédia no ético" (Tragödie im Sittlichen) na qual se misturam o irracionalismo crônico simultâneo e vinculado aos processos planetários de racionalização. ${ }^{33} \mathrm{~A}$ vida ética absoluta não pode ser instaurada por meio de um ato de arbítrio

\footnotetext{
${ }^{30}$ Cf. Naturrecht, 150-151; Direito Natural, 83-84.

${ }^{31}$ Cf. Naturrecht, 158-159; Direito Natural, p. 91-92.

${ }^{32}$ A nostalgia da Grécia, disseminada na filosofia idealista alemã, foi ultrapassada na perspectiva da dialética especulativa. Ver: TAMINIAUX, Jacques. La nostalgie de la Grèce à l'aube de l'Idéalisme Allemand. La Haye: Martinus Nijhoff, 1967. p. 206-266.

${ }^{33}$ Sobre o tema aqui meramente aludido estamos escrevendo um trabalho mais amplo. Acerca do significado do trágico em Hegel, ver o comentário de BOURGEOIS, Bernard. Op. cit. p. 447-524. Também: PIRES, Edmundo Balsemão. Op. cit. p. 210-227. Há um resumo elucidativo em: THIBODEAU, Martin. Hegel e a tragédia grega. São Paulo: É Realizações, 2015. p. 71-109. Para a discussão em contraponto com Nietzsche, ver: MENKE, Christoph. Estética y negatividad. Buenos Aires: Fondo de Cultura Económica, 2011. p. 205-233. (Devemos esta última referência ao nosso colega Prof. Dr. Gustavo Sarti Mozelli).
} 
da vontade, conforme a célebre passagem do ensaio: "o absoluto joga eternamente com ele mesmo, que ele se engendra eternamente na objetividade, desse modo se abandona nesta sua figura à sua paixão e à sua morte e de suas cinzas eleva-se na majestade". ${ }^{34}$ Hegel retoma o direito natural clássico, sobretudo de Aristóteles, mas sabe já ter passado o tempo da "bela totalidade", o seu destino agora implica a passagem pela negatividade do indivíduo e a sua realização deve se submeter a tal determinação da particularidade para ressurgir como absoluta na figura do espírito. O "Sistema de eticidade" registra essa travessia, anunciando o reconhecimento da particularidade como subjetividade e sua suprassunção no saber absoluto. ${ }^{35}$

Não é fácil acompanhar em sua exposição tortuosa e não poucas vezes obscura o movimento dialético da argumentação hegeliana em todos os seus sucessivos desdobramentos na construção da ideia de eticidade. Após curta introdução o manuscrito se divide em três partes: "a eticidade absoluta segundo a relação"; "o negativo ou a liberdade ou o crime" e "eticidade". Como sublinha um comentador o desenvolvimento sistemático do texto só pode ser compreendido a partir das categorias de "conceito" e "intuição", as quais, "numa primeira aproximação", podem ser definidas como se segue: " a intuição, quer dizer o objetivo, é 'isto que é verdadeiramente universal', enquanto que o conceito ou o subjetivo, é 'o verdadeiramente particular'. Em si, do ponto de vista da 'Ideia' eles são estritamente um, cada um identidade do conceito e da intuição e esta identidade é precisamente aquilo que se realiza na vida ética, enquanto 'ideia da vida ética absoluta'." 36

Assim, a primeira frase posta na "Introdução" do manuscrito apresenta de chofre a sua tese central: "para se conhecer a vida ética absoluta (die absolute Sittlichkeit) a intuição deve ser colocada perfeitamente adequada ao conceito, pois a ideia ela mesma não é outra coisa que a identidade entre ambos", sendo tal

\footnotetext{
34 "Es ist nichts Anders als die Aufführung der Tragödie im Sittlichen, welche das Absolute ewig mit sich selbst spielt, dass es sich ewig in die Objektivität gebiert, in dieser seiner Gestalt hiermit sich dem Leiden und dem Tode übergibt, uns sich aus seiner Asche in die Herrlichkeit erhebt". Cf. Naturrercht, 164; Direito Natural, p. 97-98.

${ }^{35}$ Conforme apontado na "Nota 20", a travessia acima aludida remete a um trabalho em andamento acerca da tensão entre o "trágico" e o "dramático" na modernidade. Sobre o destino da "bela totalidade" no limiar de nossa época, segundo Hegel, ver: JANICAUD, Dominique. Hegel et le destin de la Grèce. Paris: J. Vrin, 1975. P. 93-98. E a esclarecedora recensão de Henrique Vaz, ver; VAZ, Henrique C. de Lima. Recensão de "Dominique Janicaul. Hegel et le destin de la Grèce". Sintese, v. 3, n.6. p. 116-120, Jan./mar. 1976.

${ }^{36}$ Cf. GÉRARD, Gilbert. Critique et dialectique. L' itinéraire de Hegel à Iéna (1801-1805). Bruxelles: Facultés Universitaires Saint-Louis, 1982, p. 200.
} 
identidade apreendida segundo a subsunção recíproca entre o conceito e a intuição. ${ }^{37}$

O cerne desta introdução consiste na relação dialética, isto é, na oposição e na subsunção recíprocas, da universalidade (Allgemeinheit) e da particularidade (Besonderheit), explicitando que "a verdadeira universalidade é a intuição e a verdadeira particularidade é o conceito". A ideia enquanto intuição é um povo absoluto (ein absolutes Volk) e enquanto conceito é "o ser-uno (Einssein) absoluto das individualidades". A passagem da intuição ao conceito e deste à intuição significa que a constituição da eticidade deve ser pensada à luz da relação dialética entre a intuição do povo como unidade e a realidade múltipla das individualidades, de modo que não se pode deduzir a individualidade a partir do povo e aquela não pode dele ser abstraída. ${ }^{38}$ Tais passagens ajudam a esclarecer a linguagem de Hegel para o leitor contemporâneo: trata-se de pensar a relação tensa entre a universalidade/intuição e a particularidade/ conceito, pode-se falar em tensão porque o movimento de unificação é sempre incompleto e nesse sentido é que se pode falar do absoluto em "relação" (Verhältnis), como se pode ver no título da primeira parte do manuscrito, pois o termo "relação" indica uma dualidade ainda não suprassumida. ${ }^{39}$

\section{$1^{a}$ parte do texto: $A$ vida ética absoluta segundo a relação}

No caso da subsunção do conceito sob a intuição "a unidade é o universal" (ist die Einheit das Allgemeine) e no caso da subsunção da intuição sob o conceito a unidade volta a se confrontar com o particular. Esse é o tema fundamental da individualidade em sua relação com a comunidade. Para ele a comunidade não é o resultado da mera soma dos indivíduos, assim como o todo não é a simples soma das partes. Por outro lado, as partes não podem ser diluídas no todo e é justamente a recusa da prevalência unilateral de um elemento sobre o outro que impõe a subsunção recíproca. Logo na introdução do manuscrito o autor tinha enfatizado como a ideia da eticidade absoluta consiste em retomar a realidade como unidade e totalidade.

Esta reciprocidade entre intuição e conceito, individual e universal, interior e exterior mostra por seu caráter dinâmico que "a eticidade é um impulso",

\footnotetext{
${ }^{37} \mathrm{Cf}$. "Um die Idee der absoluten Sittlichkeit zu erkennen, muss die Anschauungen dem Begriff vollkommen adäquat gesetzt warden, den die Idee ist selbst nichts anders als die Identität beider". Sittlichkeit, p. 15.

${ }^{38}$ Cf. "Dasjenige aber, was wahrhaft das Allgemeine ist, ist die Anschauung, das wahrhaft Besondere aber der absolute Begriff [...\} Nun ist die Idee der absoluten Sittlichkeit das Zurücknehmen der absoluten Realität in sich, als in eine Einheit, so dass dieses Zurücknehmen und diese Einhait absolute Totalität ist; ihre Anschauung ist ein absolutes Volk; ihr Begriff ist das absolute Einssein der Individualitäten". Sittlichkeit, p. 15.

${ }^{39}$ Cf. :"Oder es bestimmt sich hiermit die Identität des Besondern ...und des Allgemeinen als eine unvolkommene Vereinigung oder als ein Verhältnis". Sittlichkeit, p. 16.
} 
um impulso (Trieb) inicialmente voltado para o individual, porque nele se satisfaz, mas ao mesmo tempo, vai além dele na forma da negação. A satisfação sendo identidade dinâmica de intuição e conceito encontra-se sempre num grau determinado de realização, não podendo ser nem unidade isolada, nem totalidade vazia, pois é algo simultaneamente vivo e formal, na medida em que a vida absoluta permanece no interior da individualidade e paira acima dela. ${ }^{40}$

Hegel se propõe, então, explicitar os "momentos" da relação dialética intrínseca da eticidade absoluta. O manuscrito não é claro no detalhe de suas subdivisões, porém a distinção fundamental é designada como dois movimentos que se entrecruzam na constituição da eticidade ou, utilizando a terminologia proveniente de Schelling acerca da diferenciação quantitativa da identidade, os seus dois polos são designados como duas "potências". A primeira é a "potência da natureza" (Potenz der Natur) ou subsunção do conceito sob intuição; a segunda é a "potência da infinitude" (Potenz der Unendlichkeit) ou da idealidade no formal. Estas duas potências demarcam o campo da eticidade natural.

\section{A. Primeira potência da natureza, subsunção do conceito na intuição}

Esta é definida como a "vida ética natural enquanto intuição" e, portanto, como "total indiferenciação", pois não há lugar para a particularidade. Porém, "o ético" (das Sittliche) somente surge da negação dessa indiferença da vida ética natural para se afirmar como "negativa por essência", como "identidade proveniente da diferença" ${ }^{41} \mathrm{O}$ texto nos confunde porque sintetiza de modo quase vertiginoso o movimento dialético pelo qual o particular e o universal passam um no outro: na naturalidade ética (sittliche Natürlichkeit) contrapõe "o universal contra o particular" e o faz mergulhando no particular, no sentimento enquanto ele diz respeito ao particular e ao individual. Porém em seu domínio próprio designa tanto a particularidade separada quanto a sua negação, ou seja, envolve tanto a necessidade (Bedürfnis), quanto o gozo (Genuss). ${ }^{42}$

Como compreender o movimento de interpenetração do particular e do universal em seus diversos elementos no domínio próprio do sentimento?

\footnotetext{
${ }^{40}$ Cf. "...ist die Sittlichkeit ein Trieb [...] Die Befriedigung selbst ist nichts anders, als dass der Begriff und die Anschauung Eins ist.Sie ist also Totalität, lebendig, aber formell, weil eben diese Stufe, auf der sie ist, selbst eine bestimmte ist, also das absolute Leben sowohl über ihr schwebt, als dasselbe ein Inneres bleibt..." Sittlichkeit, p. 17.

${ }^{41}$ Cf.: "Die erste Potenz ist die natürliche Sittlichkeit als Anschauung; die völlige Differenzlosigkeit derselben ... Aber das Sittliche ist an und für sich seinem Wesen nach, ein Zurücknehmen der Differenz in sich, die Rekonstruktion; die Identität geht von Differenz auf, ist ihrem Wesen nach negativ..." Sittlichkeit, p. 18.

${ }^{42}$ Cf. "Das Gefühl der Trennung ist das Bedürfnis; das Gefühl als Aufgehobensein derselben der Genuss". Sittlichkeit, p. 18.
} 
Há uma primeira polarização entre a separação ou necessidade e o ser-aniquilado do objeto (das Vernichtetsein des Objekts) ou gozo, mas como a própria polarização suscita a experiência da diferença, então entre a necessidade e o gozo se inserem o desejo (Begierde) como "determinação ideal do objeto" e o trabalho como esforço para superar a distância com relação ao objeto. Nesta primeira polarização o indivíduo movido pela necessidade a sacia por meio da devoração do objeto. No gozo (Genuss), com a aniquilação absoluta do objeto se dá uma identidade carente de razão, indiferenciada, sem intuição e, portanto, a completa indiferença do sujeito. Não há mediação entre os opostos e nem conhecimento de si por meio da intuição e esta é a esfera própria do sentimento. ${ }^{43}$ A necessidade, como comer e beber, é uma particularidade absoluta (eine absolute Eizelheit) porque nela o universal é o subsumido (das Subsumierende) e é pertencente totalmente à natureza, porque nela o objeto se mostra como algo adequado à necessidade do indivíduo, algo comível ou bebível, mas a ele se opõe como pura exterioridade. ${ }^{44}$

Mas sendo "o gozo puramente sensível" o seu resultado é "a restauração da indiferença e do vazio do indivíduo" e como tal abre a possibilidade de um novo movimento na constituição da vida ética. ${ }^{45}$ Se no gozo a separação entre o subjetivo e o objetivo é negada na indiferença, logo uma segunda negação se impõe como passagem para o domínio do desejo quando a separação entre sujeito e objeto é trabalhada, mas não negada. O trabalho enquanto intuir prático negativo sobre as coisas as modifica, opera a transformação do objeto e, assim, interfere na separação entre o sujeito e o objeto, porém sem destruí-la. Desse modo, "o objeto não é aniquilado como objeto em geral", mas "outro objeto é posto em seu lugar". Com a instauração da deriva dos objetos passa a não mais haver a simples aniquilação, como no gozo, mas há trabalho e neste o objeto determinado pelo desejo é suprassumido (aufgehoben) e intuído em sua objetividade, por conseguinte "no trabalho é posta a diferença entre o desejo e o gozo, este é impedido ou adiado". ${ }^{46}$

\footnotetext{
${ }^{43}$ Cf. "Das praktische Gefühl, oder der Genuss, eine anschauungs- und differenz-, und also vernunftlose Identität, welches also auf absolute Vernichtung des Objektes geht, und ebenso eine völlige Indifferenz des Subjekts, für das Sittliche ohne Herausheben einer die Entgegengesetzten in sich vereinigenden Mitte ist, also das Zurücknehmen des Anschauens in sich selbst nicht, also kein Erkennen seiner in demselben ist". Sittlichkeit, p. 19.

${ }^{44}$ Sittlichkeit, p. 19.

${ }^{45}$ Sittlichkeit, p. 20.

46 “...das Objekt nicht vernichtet, als Objekt überhaupt, sondern so dass ein andres an seine Stelle gesetzt wird; denn es ist, in diesem Vernichten, als der Abstraktion, nicht das Objekt, oder es ist nicht der Genuss. Dieses Vernichten aber ist die Arbeit; durch/ welche das durch die Begierde bestimmte (Objekt), insofern es für sich, ein durch die Begierde nicht bestimmtes, für sich reell ist, aufgehoben, und das Bestimmtsein durch die Begierde, als Anschauung, objektiv gesetzt wird ; es ist im Arbeiten die Differenz der Begierde und des Genusses gesetzt; dieser ist gehemmt, und aufgeschoben, er wird ideell, oder ein Verhältnis..." Sittlichkeit, p. 20-21. Traduzimos "aufgehoben" por "suprassumido", em consonância com a proposta do Prof. Paulo Meneses SJ tradutor brasileiro da "Fenomenologia do Espírito".
} 
A consequência imediata do trabalho é a "tomada de posse" (Besitzergreiffung), no entanto, temos agora não apenas a aniquilação do objeto em sua matéria, mas sua transformação designada como sendo "a aniquilação real de sua forma" e esta viabiliza o armazenamento e preservação do objeto estabelecendo as condições para a ideia de propriedade. No entanto, a questão da posse e da propriedade está localizada na segunda potência referida à idealidade e formalidade das relações e não se situa no campo da natureza ${ }^{47} \mathrm{Na}$ primeira potência o objeto devorado não foi transformado pela ação do trabalho e não há nesta primeira relação natural qualquer implicação jurídica, o que passa a ocorrer somente quando intervém a ação transformadora do trabalho. Pode-se dizer, então, que não é crime pegar uma fruta na natureza e comê-la, mas se a retirarmos de um pomar, estamos invadindo uma propriedade.

A relação de exterioridade entre o indivíduo e o objeto é determinada pela necessidade e, por meio do gozo, esta é negada pela aniquilação do objeto. Se a satisfação fosse completa nada mais haveria, porém se a incorporação do objeto sustenta a vida do indivíduo, vê-se que, após o gozo, se apresenta novamente como vazio e falta. O círculo não se fecha, porque a negação pura engendra a passagem para o nível do desejo e este, por sua vez, exige o trabalho enquanto transformador do objeto natural em objeto ideal. Pode-se dizer numa linguagem figurativa que o primeiro plano constituído por noções como necessidade, objeto natural e gozo se desdobra num segundo plano constituído por vida, desejo e trabalho. Não há uma transição linear do primeiro para o segundo plano, passível de ser explicada por meio da causalidade e tampouco independência do segundo em relação ao primeiro como se este fosse anulado. Os planos passam um no outro numa identidade viva ou, como diz Hegel: " para o objeto vivo que subsume e para o trabalho vivo, há inicialmente a intuição subsumida sob o conceito e, depois, o conceito sob a intuição e, então, a identidade de ambos". 48

A transição de um plano ou domínio ao outro não é meramente quantitativa, daí o caráter irredutível da vida em geral e, o mais importante, a transição só pode ser pensada a partir da identidade, isto é, a partir da Ideia. Não há um olhar externo acerca dessas relações, elas somente podem ser compreendidas a partir de sua lógica interna. Ou, se quisermos, podemos dizer que a vida não é pensável a partir da não-vida, assim como a vida ética não é pensável a partir da vida meramente biológica, pois na planta e no animal reina a multiplicidade, a dispersão, a carência de uma individualidade forte, porque neles há somente uma relação extrínseca ou

\footnotetext{
${ }^{47}$ Sittlichkeit, p. 21.

48 "Es ist für das subsumierende lebendige Objekt und die lebendige Arbeit die Anschauung unter den Begriff subsumiert, dann unter die Anschauung der Begriff, und dann die Identität von beiden". Sittlichkeit, p. 22.
} 
não mediatizada entre a particularidade e a universalidade. No homem o trabalho em sentido genérico surge como formação e transformação segundo três potências: a relação sexual ou amorosa, a relação de pais e filhos e as relações de trabalho em sentido específico. ${ }^{49}$ Apesar de enfatizar a terceira modalidade relacional, o texto também sublinha a importância da filiação para a construção da eticidade absoluta, pois na relação de pais e filhos o ser-um é cindido e o trabalho dos pais consiste justamente em suprassumir esta relação de modo a tornar a "negatividade externa da criança" em negatividade interna e, portanto, numa "mais elevada individualidade"..$^{50} \mathrm{~A}$ posição inversa entre pais e filhos permite a transmissão da determinidade empírica do ser de um ao outro, porém possibilitando numa forma negativa o estabelecimento de laços comunitários, embora anteriores àqueles de uma efetiva ordenação política. ${ }^{51} \mathrm{O}$ processo natural da transmissão empírica de pais a filhos é atravessado pela mediação do trabalho transformador, o qual, não obstante, não produz um excedente (Überfluss).

Na esfera da eticidade natural o trabalho emerge nas relações parentais, pois a diferença natural entre pais e filhos, entre as gerações é mediada pelo utensílio (Werkzeug). ${ }^{52}$ Hegel mostra como o utensílio cumpre o papel de mediação entre o subjetivo e o objetivo e com tal função de termo médio deve ser dotado de racionalidade intrínseca. O utensílio tomado em seu papel mediador não deve ser inteiramente identificado com a ferramenta em seu significado material. Assim, diz Hegel, na formação da criança este "meio racional ideal é o discurso (Rede), o instrumento (Werkzeug) da razão, o filho do ser inteligente" e, esclarece, "a substância do discurso é como a criança o que há de mais indeterminado, de mais puro, de mais negativo, de mais assexuado e capaz de todas as formas em razão de sua maleabilidade e transparência absolutas; sua realidade é completamente capturada na idealidade e ao mesmo tempo ela é individual; ela tem uma forma ou uma realidade, ela é um sujeito, um ente para si..." 53

\footnotetext{
${ }^{49}$ Sittlichkeit, p. 25-26.

50 "Die Eltern sind das Allgemeine, und die Arbeit der Natur geht auf die Aufhebung dieses Verhältnisses, so wie die der Eltern, welche die äussere Negativität des Kindes immer mehr aufheben und ebendadurch eine grössere innere Negativität und damit höhere Individualität setzen". Sittlichkeit, p. 26.

51 "Die Form oder die Unendlichkeit ist also die empirische, negative des Andersseins, welches eine Bestimmtheit nur dadurch aufhebt, dass es eine andere setzt, und eben nur positive immer in einem andern ist. Die Macht und der Verstand, die Differenz der Eltern, steht im umgekehrten Verhältnis mit der Jugendlichkeit und Kraft des Kindes, und diese beiden Seiten des Lebens fliehen sich und folgen aufeinander und sind aussereinander". Sittlichkeit, p. 45. Ver: REICH, Evânia. O reconhecimento em Hegel. 2012, p. 25.

${ }^{52}$ Sittlichkeit, p. 27.

53 "Diese ideelle vernünftige Mitte ist die Rede, das Werkzeug der Vernunft, das Kind der intelligenten Wesen. Die Substanz der Rede ist wie das Kind, das Unbestimmteste, Reinste, Negativste, Geschlechtsloseste, und um ihrer absoluten Weichheit und Durchsichtigkeit willen aller Formen fähig; ihre Realität ist vollkommen in die Idealität aufgenommen, und sie zugleich individuell; sie har Form oder eine Realität, sie ist ein Subjekt, ein für sich Seiendes..." Sittlichkeit, p. 29.
} 
O trecho anteriormente citado sintetiza como a individualidade humana difere radicalmente da individualidade meramente empírica e fraca das plantas e da dispersão dos animais porque se forma como individualidade a partir da pura negatividade, da indeterminação e possibilidades absolutas. A negatividade provém da linguagem enquanto "mediação das inteligências, Logos, o próprio vínculo racional" e a linguagem sendo discurso sonoro não se confunde com o som, com o "murmúrio das águas", "o grito dos animais", não se confunde com a mera sensação como reação ao ambiente natural. As linguagens não humanas não "provem da inteligência e nem da metamorfose anterior da natureza em algo subjetivo. Falta ao animal a solidão absoluta na qual a natureza se encontra no interior da inteligência" Apesar de se falar em metamorfose da natureza não se deve pensar numa espécie de evolução natural, desse modo a expressão "solidão absoluta" (die absolute Eisamkeit) ausente nos animais assinala a introdução da negatividade da linguagem como "irrupção absoluta" (das absolute Einbrechen), como sendo a condição singular do humano com relação à pura exterioridade da natureza. Aqui o indivíduo humano não é apenas particularidade abstrata, porque ele mesmo é "encarnação da linguagem" (die Körperlichkeit der Rede). ${ }^{55}$

A linguagem, conclui Hegel, "é a flor mais elevada da primeira potência" cujo "negativo é a necessidade, a morte natural, a violência e devastação da natureza, também o confronto dos homens entre si ou em relação à natureza orgânica, mas relação natural". ${ }^{56}$ Nesse pondo da exposição gostaríamos de enfatizar como já aparecem nesse escrito de juventude, tanto a clara recusa da naturalização do humano e, por conseguinte, a impropriedade de se pensar o ético a partir do indivíduo empírico, quanto a recusa da dissolução da riqueza e singularidade da individualidade em esquemas totalizantes e abstratos.

\section{B) Segunda potência da infinidade, idealidade, no formal ou na relação}

A primeira potência consiste no domínio da natureza ou, na terminologia de Hegel, na subsunção do conceito sob a intuição. Vimos que nele o desdobramento dialético dos diversos momentos deságua na individua-

\footnotetext{
${ }^{54}$ Sittlichkeit, p. 31.

${ }^{55}$ Sittlichkeit, p. 31.

56 "Sie ist die höchste Blütte der ersten Potenz (...) Das Negative dieser Potenz ist Not, der natürliche Tod, die Gewalt und Verwüstung der Natur, auch der Menschen gegeneinander oder Verhältnis zur organischen Natur; aber ein natürliches Verhältnis". Sittlichkeit, p. 31. Uma das dificuldades encontradas pelo leitor do texto reside justamente na não linearidade da exposição uma vez que esta já se coloca do ponto de vista do absoluto. O "natural" não é cronologicamente anterior e separado do espírito como temos o hábito de pensar. Nele já encontramos a "potência" da linguagem, seja na acepção aristotélica, de ser de alguma
} 
lidade humana como resultado da formação humana pela mediação da linguagem. A segunda potência, por outro lado, consiste na subsunção da intuição sob o conceito. Como se pode interpretar essa passagem? Não é fácil acompanhar essa inversão dialética porque se trata de entender como o particular torna-se determinado pelo universal entendido como "surgimento" do ideal. A dominação do universal significa submeter a singularidade viva - como foi visto anteriormente com relação ao amor, à formação da criança e ao discurso - à fixidez da forma. Isso ocorre porque agora tudo se refere ao outro na estranheza de sua alteridade ou, como diz Hegel, "nesta potência nada deixaria de ter relação a outras inteligências". ${ }^{57}$

O movimento da subsunção recíproca entre conceito e intuição, entre particularidade e universalidade se dá a partir da consideração do trabalho em seu sentido próprio, ou seja, a modificação do objeto na produção do "excedente" (Überfluss). A acumulação do excedente suscita a posse e a propriedade e estas por sua vez impõem o processo de institucionalização e de regulação das trocas. No primeiro momento, designado como potência da natureza, Hegel enumera três modos não formalizados de relacionamento entre os homens: sexo e amor, filiação e o trabalho propriamente dito. Apenas no terceiro modo aparece a palavra reconhecimento porque, ao contrário dos anteriores, somente então emerge a reciprocidade como luta de duas consciências em busca do reconhecimento. Ou seja, a reflexão sobre o problema do reconhecimento reaparece no ponto em que o autor se dedica a estudar os desdobramentos das relações de trabalho a partir da produção do excedente e a criação da posse e propriedade, precisamente no segundo momento da eticidade natural denominado de potência formal.

Em primeiro lugar há o trabalho como puramente exterior e quantitativo, como trabalho mecânico, quando o utensílio se transforma em máquina. Em segundo lugar, dele resulta para o sujeito a "pura quantidade" abstrata e esta ultrapassa as necessidades e nesta medida a "posse perdeu o seu significado para o sentimento prático do sujeito, não é mais para ele necessidade, mas excedente", a posse do excedente pensada em sua universalidade é abstração, porque está separada do sujeito. ${ }^{58}$ Em terceiro lugar, conclui-se, a "posse nessa perspectiva é propriedade, mas a aí a abstração da universalidade é o direito (...) o indivíduo em e para si não é proprietário e possuidor de direito absoluto; a sua personalidade ou a abstração de sua unidade e singularidade é

\footnotetext{
forma todas as coisas, seja porque nela já há a presença ínsita da intersubjetividade. Já há, diz Santos em seu luminoso ensaio sobre a "Fenomenologia do Espírito", "transcendência imanente". Cf. SANTOS, José Henrique. O trabalho do negativo. Ensaios sobre a 'Fenomenologia do Espírito'. São Paulo: Edições Loyola, 2007. p. 52-57.

57 ",, , so ist in dieser Potenz nichts, was nicht Beziehung auf andere Intelligenzen hätte..." Sittlichkeit, p. 32.

58 "So hat dieser Besitz seine Bedeutung auf das praktische Gefühl des Subjekts verloren, ist nicht mehr Bedürfnis für dasselbe, sondern Überfluss;..." Sittlichkeit, p. 33.
} 
meramente uma abstração e uma coisa de pensamento (Gedankending) (...) O direito de propriedade é o direito ao direito" ${ }^{59}$

O universal e o particular se contrapõem sem que a contraposição entre os termos possa ser determinada de modo fixo, porque passam um no outro ao tecerem o desdobramento da necessidade e da fruição em propriedade, contrato e troca, mas já aí a descrição empírica de todo esse processo pressupõe a introdução ainda abstrata do valor e do direito.$^{60} \mathrm{Ou}$ seja, o trabalho considerado não mais como arte ou formação, mas em seu sentido específico como produção de excedente nos exige pensar tanto o destino do excedente, quanto as vicissitudes da relação entre a consciência que tem a posse e a consciência que operou uma ação de transformação sobre a coisa. Sobre o excedente podemos afirmar que este possibilitou a criação da ideia de posse e de propriedade justamente porque o objeto transformado pode ser armazenado e conservado e sua posse cria o espaço da troca, uma vez que o objeto armazenado não se destina à pura fruição como ocorre no domínio da primeira potência prática. Por outro lado, a outra consciência não elaborou o objeto para seu uso, mas o objeto contém o seu próprio trabalho. $\mathrm{O}$ trabalho embutido no objeto pode ser acessado através do valor e do preço do objeto. O excedente que se revela para uma consciência como posse e propriedade, se apresenta para outra consciência como valor e preço, sendo o encontro dessa pluralidade humana a condição da troca e esta o meio no qual as consciências se reconhecem reciprocamente. Do caráter empírico das trocas emerge a universalidade do contrato o qual transforma a particularidade das diferenças empíricas em indiferença universal. $\mathrm{Ou}$, no dizer de Hegel: "esta transformação da troca é o contrato... com ele a pura troca torna-se um meio racional" ${ }^{61}$ A racionalidade do contrato suprime as particularidades empíricas enquanto vistas como condição da troca, pois nele o indivíduo é subsumido, o seu "arbítrio e particularidade são suprassumidos, pois no contrato se apela a esta absoluta universalidade". ${ }^{62}$

A indiferença universal é o domínio da abstração, do dinheiro e do comércio como circulação dos excedentes. Todavia, aí mesmo podemos discernir o indivíduo como "um vivente formal"(ein formal lebendiges). Por que vivente e formal? Porque o tomamos formalmente como vazio de todas as "determinações particulares" nesse mesmo aspecto a vida pode ser considerada como a "mais alta indiferença do individual". ${ }^{63}$ Por conseguinte o indivíduo,

\footnotetext{
59 " Besitz ist in dieser Rücksicht Eigentum; die Abstraktion der Allgemeinheit an demselben aber ist das Recht (...) Das Individuum ist Eigentümer, rechtlicher Besitzer nicht absolut, an und für sich; seine Persönlichkeit oder die Abstraktion seiner/ Einheit und Einzelheit ist bloss eine Abstraktion und ein Gedankending...Recht an Eigentum ist Recht an Recht". Sittlichkeit, p. 34.

${ }^{60}$ Sittlichkeit, p. 36.

61 "Diese Verwandlung des Tausches ist der Vertrag. In ihm bildet sich der Moment der absolutan Gegenwart, der im reinen Tausch ist, zu einer vernünftigen Mitte..." Sittlichkeit, p. 37.

62 Sittlichkeit, p. 38.

${ }^{63}$ Sittlichkeit, p. 39.
} 
tomado como ser-vivo em geral, pode ser o "contrário de si mesmo", pode ser compreendido como liberdade e esta traz consigo a possibilidade "do não reconhecimento e da não liberdade". ${ }^{64}$ Nesse horizonte ainda abstrato da liberdade os indivíduos entram em confronto uns com os outros, com suas diferenças e poderes desiguais, e as possibilidades do reconhecer e do não reconhecer dos indivíduos livres constituem "a relação da dominação $e$ da servidão" ${ }^{65}$ A relação de senhorio e servidão se refere à multiplicidade abstrata dos indivíduos e, nesse sentido, ainda não é regida pela eticidade absoluta a qual implica a unidade para além da multiplicidade. A expressão "para além" aponta para um nível radicalmente diferente daquele da oposição meramente quantitativa entre a multiplicidade empírica e a unidade vazia, pois nele deve ser realizada a exigência lógica segundo a qual a unidade só pode ser pensada na multiplicidade e vice-versa. Encontramos aqui o nervo da reciprocidade dialética entre o conceito e a intuição, o particular e o universal, o que exclui a interpretação do processo como uma gênese empírica e contingente da vida ética a partir da pluralidade dos indivíduos considerados no "estado de natureza". ${ }^{66}$

Já encontramos aqui, ao final da exposição da primeira parte do "Sistema da eticidade" alguns elementos essenciais do pensamento hegeliano que seriam plenamente desenvolvidos em sua concepção madura acerca do direito natural e da ciência política. O caráter por vezes labiríntico do escrito no esforço de relacionar "trabalho excedente" e "troca", "contrato" e "valor" decorrem da sua busca de conseguir manter-se equidistante tanto do liberalismo econômico, visto pelo ângulo da pauperização existente na Inglaterra, quanto da planificação econômica integral, defendida por Fichte e que levaria à destruição da liberdade dos indivíduos. A busca de uma via intermediária na proposição de uma teoria contraditória do valor só poderia ser avaliada a partir dos desenvolvimentos da obra de maturidade. ${ }^{67}$ De qualquer modo neste escrito de juventude já nos parece manifesto o caminho, ainda incerto do ponto de vista metódico, direcionado para a suprassunção da tradição da

\footnotetext{
${ }^{64}$ Sittlichkeit, p. 40.

65 “Dieses Verhältnis, dass das indifferente und freie, das mächtige ist, gegen das Differente, ist das Verhältnis der Herrschaft und Knechtschaft". Sittlichkeit, p. 40.

${ }^{66}$ Sobre o estatuto lógico ou ontológico da natureza ver "Nota 43". Como observa Santos: "A teoria da dominação e da servidão no Sistema de vida ética" se baseia na desigualdade de força e pertence à esfera da natureza. Por isso a igualdade do reconhecimento recíproco é apenas uma possibilidade pensada e não uma possibilidade real". Cf. SANTOS, José Henrique. Trabalho e riqueza na 'Fenomenologia do espírito' de Hegel. São Paulo: Edições Loyola, 1993. p. 35. Não custa ressaltar mais uma vez que a realidade da natureza e do espírito não estão "fora" do domínio do "lógico" (das Logische). Afinal o tema possui relevância política como já foi aludido acerca da controvérsia sobre a "identidade" entre o "racional" e o "efetivo" (wirklich). Sobre a "passagem" da Ideia à natureza e sua leitura marxiana ver: CARON, Maxence. Être et identité. Méditation sur la Logique de Hegel. Paris: Éditions Du Cerf, 2006. p. 309-315.

${ }^{67}$ Para uma discussão da questão, ver: DENIS, Henri. Logique hégélienne et systèmes économiques. Paris: PUF, 1984. Para a crítica do liberalismo e da planificação, cf.: p. 32-35.
} 
filosofia política moderna, visando dela retirar os pressupostos individualistas e, assim, promover a reaproximação com o pensamento clássico platônico e aristotélico, porém mantendo daquela tradição a ideia de liberdade como sua pedra angular. Não custa reiterar o que já foi dito no início deste artigo e vemos claramente afirmado pelo filósofo no início de suas "Lições sobre a filosofia do direito" de 1818-1819: "o princípio do direito não se encontra na natureza. A esfera do direito é a esfera da liberdade" ${ }^{68}$ Como observa Ilting acerca da "ideia racional do direito": "trata-se, portanto, de conceber as normas fundamentais do direito privado e público como um sistema de normas capazes de serem justificadas com a razão, na medida em que elas são condições de realização da liberdade e da autonomia de um ser racional (...) por conseguinte, Hegel vê como ultrapassados todas as tentativas de derivar o direito natural de uma tendência natural ou antes de um instinto social". 69

Por um lado, a sociedade não pode ser concebida a partir da natureza ou dos indivíduos considerados abstratamente em seu estado de natureza, por outro lado, a moralidade não pode ser concebida a partir das instituições do Estado. Como ainda observa Ilting "o caráter provisório do direito no estado de natureza não pode ser superado diretamente pela criação de instituições politicas (estatais), mas somente indiretamente criando antes uma base moral para a realização do direito. Por esta razão, Hegel não fala, na segunda parte de sua obra, do Estado, mas da moralidade". ${ }^{70}$

A rejeição do naturalismo no artigo sobre o direito natural e no manuscrito do "Sistema de eticidade" coloca um desafio filosófico de grande complexidade, porque "a base moral para a realização do direito" não pode mais ser pensada no sentido da moralidade kantiana ainda excessivamente dependente da tradição individualista moderna. Para ultrapassar tanto o naturalismo, quanto o individualismo modernos em direção à eticidade como fundamento do Estado e, contudo, sem retornar simplesmente à concepção clássica, foi necessário construir um novo arcabouço ontológico e/ou metafísico para pensar o humano em seu caráter singular e irredutível, projeto somente possível se o mesmo ato de pensar for referido à inteligibilidade do ser. $\mathrm{Na}$ economia de nossa exposição não há como entrar em problema tão amplo e difícil no qual está em jogo o estatuto da dialética em seu sentido propriamente idealista segundo o qual o inteligível não pode ser apreendido pela consciência finita senão em seu caráter intrinsecamente processual. De qualquer forma basta-nos aqui assinalar como a entrada na terra prometida da vida ética ou da eticidade absoluta (Sittlichkeit) exige a passagem pelo aprofundamento e pela

${ }^{68}$ Cf HEGEL, G.W. F. Vorlesungen über Rechtsphilosophie, op. cit. § 3.

${ }^{69}$ ILTING, Karl-Heinz. "La forme logique et systématique de la 'Philosophie du droit'". In: WEIL, Eric et alii. Hegel et la philosophie du droit. Paris: PUF, 1970. p. 39-40.

${ }^{70}$ Idem, p. 42. 
dor da negatividade. A segunda parte do manuscrito trata justamente do crime e da liberdade como "suprassunção da determinidade". No que se segue iremos apresentar de modo muito breve e esquemático as segunda e terceira partes do manuscrito de Hegel sem acompanhar com detalhe os seus desenvolvimentos mais específicos. ${ }^{71}$

\section{$2^{\underline{a}}$. parte do texto: $O$ negativo ou a liberdade ou o crime}

Nesta segunda parte do texto o ponto de vista da particularidade ou da subsunção da intuição sob o conceito é deixada para trás, ou seja, o processo dialético até aqui descrito "tem como princípio a particularidade; é o absoluto subsumido sob o conceito". Se nele prevalecem as particularidades ou determinidades (Bestimmtheiten), estas agora devem ser suprassumidas na "universalidade absoluta", mas tal movimento somente é possível por meio da negatividade pura. ${ }^{72}$ Como o negativo não é fixado, então ele deve ser entendido como passagem para a "eticidade absoluta", quando esta "se eleva acima determinidade porque o negativo a suprassume, porém de modo que ele a reunifica com seu contrário em algo superior e, portanto, em verdade não o deixa subsistir e o coloca somente com significação negativa, mas ela suprassume a sua forma ou idealidade, por meio da identidade realizada com, seu oposto, tomando-lhe o negativo e o tornando absolutamente positivo ou real". ${ }^{73} \mathrm{~A}$ citação mais longa que acabamos de fazer se justifica não só por mostrar o negativo como enriquecimento da identidade, mas também por não valorizar o negativo de modo unilateral como se vê num exemplo dado logo em seguida: a sensação da cor vermelha pode ser negada ou transformada pela "liberdade da inteligência" em cor vermelha pensada, embora aquela permaneça, pois, como diz o filósofo, a sensação recolhida no infinito ainda se mantém em sua particularidade finita. ${ }^{74}$

Neste ponto do argumento a ideia de violência aparece como um momento inerente ao movimento dialético. Não se trata pura e simples de destruição porque a ideia de violência aparece como modo de pensar analogicamente o emergir da vida ética. Conforme escreve Hegel "um assassinato suprime (aufhebt) o vivente enquanto particularidade, como sujeito, mas a vida ética o faz

\footnotetext{
${ }^{71}$ A análise detalhada da segunda e da terceira partes foram feitas para serem inseridas num trabalho ainda em andamento acerca da relação do crime com o estatuto do reconhecimento no jovem Hegel e o seu lugar específico no conjunto do sistema.

72 Sittlichkeit, p. 45.

73 "Die absolute Sittlichkeit erhebt sich über die Bestimmtheit dadurch, dass es sie aufhebt, aber so, dass es sie in einem Höhern mit ihrem Entgegengesetzten vereinigt, also nicht in Wahrheit es bestehen lässt und nur mit negativer Bedeutung setzt, sondern durch die vollkommene Identität mit seinem Gegenteil seine Form, oder Idealität aufhebt, gerade ihm das Negative nimmt und es absolut positiv oder reell macht." Sittlichkeit, p. 46 .

${ }^{74}$ Sittlichkeit, p. 46-47.
} 
do mesmo modo; no entanto, a vida ética suprime a subjetividade, a determinidade ideal, enquanto o assassinato suprime sua objetividade, o coloca como um negativo, particular, que retorna sob a violência do objetivo, do qual, com isso, foi arrebatado, pois ele mesmo era um objetivo". ${ }^{75}$ Por que falar aqui em analogia? Porque no mesmo termo (Gewalt) encontramos semelhanças e diferenças com relação ao que entendemos espontaneamente como violência. Esta enquanto momento dialético na constituição da eticidade pode ser compreendida como sendo oposta à "violência" natural, por isso, continua o texto, "a vida ética absoluta suprime imediatamente a subjetividade, mas ela a aniquila somente como determinidade ideal, mas deixa subsistir simplesmente a sua essência e a torna justamente subsistente e real, pois deixa ser sua essência, o que ela é; a inteligência enquanto tal permanece na vida ética.". ${ }^{76}$

A consideração da vida ética não pode colocar a violência como um dado externo pertencente à natureza, mas ao contrário, como elemento estrutural da cultura ela se contrapõe à natureza, isto é, ela só deve ser concebida a partir da exigência de suprassunção da subjetividade em sua particularidade na construção da comunidade. Nada obstante, a presença desse elemento hobesiano não significa a palavra final da concepção hegeliana, pois embora a violência seja uma condição constitutiva da eticidade não é o seu fundamento. Tomamos a liberdade de citar mais longamente um comentário esclarecedor, embora voltado à "Filosofia do direito", por nos ajudar a compreender melhor esse ponto crucial: "certamente Hegel não faz desta violência o fundamento do direito, mas ele aí vê a passagem (Übergang) obrigatória ao estado de direito; ele dela não faz a substância do Estado mas nela ele reconhece seu 'necessário começo' fenomenal (erscheinender Anfang). Essa "coação pedagógica" (pädagogischer Zwang) que se opõe à 'vontade inculta' (ungebildeter Wille), violência sem a qual o universal não pode se efetuar, (a bondade é impotente para abolir o estado de natureza) ...violência produtora de "eticidade" (...) é uma violência que não é contrária ao direito porque reprimindo a selvageria natural, ela toma a liberdade sob sua salvaguarda. A liberdade não é um fato da natureza, mas um fato da sociedade. O estado de natureza é o estado de violência absoluta, quer dizer de não-liberdade, que somente a violência heroica pode começar a suprimir limitando o exercício do livre-arbítrio singular". ${ }^{77}$ A violência em seu sentido próprio se distingue da agressividade natural, que somente pode ser pensada à luz da cultura e esta não pode ser concebida sem o conflito com os seus gradientes de violência.

Ao articular violência e eticidade Hegel procura compreender o desenvolvimento efetivo da sociedade humana sem se entregar às utopias e se esfor-

\footnotetext{
75 Sittlichkeit, p. 47.

76 Sittlichkeit, 47-48.

77 MERCIER-JOSA, Solange. "Combat pour la reconnaissance et criminalité". In: HENRICH, Dieter und HORSTMANN, Rolf-Peter (hg). Hegels Philosophie des Rechts. Die Theorie der Rechtsformen und ihre Logik. Stuttgart: Klett-Cotta, 1982. p. 76-78.
} 
çando em apreender o sentido racional do conflito. Mas reconhecer o caráter inteligível do negativo não significa aceitar a inviabilidade da vida ética por conceder à violência a última palavra da história. Ao contrário, visa mostrar que sendo essencialmente comunitária a vida ética não pode ser pensada sob o prisma do subjetivismo moderno e de sua manifestação política nas diversas formas de individualismo. Para uma melhor elucidação teríamos de evidenciar esse momento da exposição por meio da análise dos diversos tipos de crime nomeados por Hegel: a barbárie, o roubo, o crime contra a honra. Mas não há como recuperar aqui tais análises, por conseguinte vamos nos ater a uma rápida observação conclusiva acerca da segunda parte do texto.

O crime mostra que a negação se coloca frente à determinação, ao particular, e, assim, ao fazê-lo pode ser conectado à "justiça vingadora"; porém, a negação também, "deve se submeter a uma ação oposta" de modo que sua inversão ideal é a consciência moral (Gewissen). A consciência moral pode ser entendida como um alcançar da verdade segundo a qual o criminoso também se fere, pois "o crime cometido no estranho é também cometido em si próprio". ${ }^{78}$ A consciência moral, representa a parte interna da oposição enquanto a justiça vingadora a sua parte externa. A tensão entre esses dois aspectos do crime revela a insuficiência e a impotência da consciência moral frente à exterioridade do ato e a impele em direção à totalidade. ${ }^{79}$ Este combate no interior da consciência moral incompleta encontra sua reconciliação e quietude apenas diante o perigo de morte. $\mathrm{O}$ círculo vicioso entre o ato criminoso e a consciência moral provém da unilateralidade da consciência moral ainda situada no espaço da multiplicidade próprio à eticidade natural.

Não há como prosseguir com um exame minucioso do texto. De qualquer forma podemos reiterar e ressaltar que Hegel no "Sistema de eticidade" continua a polemizar com Kant, ao sublinhar a insuficiência da consciência moral como fundamento da vida ética, e com Fichte, ao apontar para os riscos contidos na ideia de um estado racional inteiramente realizado no qual não haveria lugar para a liberdade individual. ${ }^{80} \mathrm{Em}$ ambos os casos o vício de origem se encontraria na primazia moderna concedida à subjetividade e aos dualismos inevitáveis daí decorrentes. Ora, imaginar uma sociedade transparente, sem confrontos dilacerantes e plenamente reconciliada consigo mesma seria ceder a uma perigosa fantasia e desconhecer o caráter trágico, mas não inteligível, permanentemente presente na história.

\footnotetext{
${ }^{78}$ Sittlichkeit, p. 49.

79 “Weil es ein Inneres, Unvollständiges ist, so treibt es zu einer Totalität". Sittlichkeit, p. 49.

${ }^{80}$ Aqui nos interessa apenas o esclarecimento interno da posição hegeliana. Não avaliamos aqui a pertinência das críticas feitas por Hegel a Fichte no "Differenzschrift". Sobre as diversas imagens de Fichte, inclusive a de Hegel e a questão do "modelo do Estado fechado", ver: MAESSCHALK, Marc. Droit et creation sociale chez Fichte. Une philosophie politique de l'action moderne. Louvain-Paris: Éditions Peeters, 1996. p. 1-36 e p. 159-183.
} 
Toda problemática do crime e da violência só pode ser abordada quando o ser-singular, quando a subjetividade, foi suprassumida na totalidade. Muitos equívocos podem surgir desse tipo de formulação como se o indivíduo fosse simplesmente aniquilado em nome da prevalência da totalidade. Como foi visto Hegel rejeita a perigosa utopia de uma sociedade fechada em sua pretensa racionalidade. Porém, ele também considera como insatisfatório o suposto "subjetivismo" kantiano e daí a sua crítica da consciência moral. O sentido de sua crítica somente pode ser avaliado à luz de seu projeto de uma metafísica irredutível ao entendimento finito e na medida em que, segundo estabelece a "Introdução" da "Ciência da lógica", a dialética não mais recue diante da "coisa em si mesma" e não mais se prenda ao "abstrato-negativo" de uma razão "incapaz de conhecer o infinito" e paradoxalmente "incapaz de conhecer o racional", pois "o infinito é o racional". ${ }^{81}$ Não há como adentrar em terreno tão inóspito, embora a simples menção do problema nos sirva como sucinta indicação da dificuldade e originalidade da concepção que, de alguma forma, já antecipa o pensamento maduro do filósofo, ainda apenas em esboço no "Sistema de eticidade".

Feita a advertência podemos dizer que na terceira parte do texto já nos colocamos no ponto de visa da "Ideia", ou seja, daquele momento no qual as oposições entre conceito e intuição, particular e universal, subjetivo e objetivo foram suprassumidos na identidade que se realiza na vida ética. Esse é o elemento da totalidade ou conforme Hegel tal é a ideia de "Povo" ${ }^{82}$ Aqui nos limitamos a uma simples observação baseada nos parágrafos iniciais da terceira parte anteriores à primeira seção dedicada à "constituição do estado".

\section{$3^{a}$. parte do texto: eticidade (vida ética)}

Qual a diferença entre a vida ética natural e a absoluta? Hegel explica que nos momentos anteriores ainda nos encontramos no domínio da "totalidade da particularidade", seja esta tomada enquanto tal ou em seu

${ }^{81}$ HEGEL, G.W.F. Ciência da lógica. 1. A doutrina do ser. Trad. Christian Iber, Marloren Miranda e Federico Orsini. Petrópolis, RJ: Vozes; Bragança Paulista, SP: Editora Universitária São Francisco, p. 52 e 59. Ver: LARDIC, Jean-Marie. L'infini et sa logique. Étude sur Hegel. Paris: Éditions L'Harmattan, 1995. p. 10-30.

${ }^{82}$ Sobre a estrutura global do sistema de eticidade ver: GÉRARD, Gilbert. Critique et dialectique. L' itinéraire de Hegel à Iéna (1801-1805), op. cit. p. 199-204. O autor aí discute as divergências de interpretação entre Jacques Taminiaux, tradutor francês do texto de Hegel e o estudioso alemão Heinz Kimmerle. Para este, "o desenvolvimento sistemático da 'ideia de eticidade absoluta', que Hegel procurou mostrar no Sistema de eticidade na primavera de 1803 em contraposição (ao ensaio sobre o direito natural) foi construída à partir de uma outra estrutura lógica". Cf. KIMMERLR, Heinz. Das Problem der Abgeschlossenheit des Denkens. Hegels "System der Philosophie" in den Jahren 1800-1804. Bonn: Bouvier Verlag, 1982, p. 67. (Hegel-Studien, Beiheft 8). Não entramos no mérito desta controvérsia, apenas seguimos a exposição de Gilbert Gérard em conformidade com Jacques Taminiaux. 
aspecto de "universalidade enquanto unidade abstrata". ${ }^{83}$ Os indivíduos em seu caráter de ser-particular têm a capacidade de estabelecer relações de reconhecimento entre si, por exemplo, de um homem qualquer com a sua mulher, seus filhos e servos e, assim, a sua liberdade se apresenta de modo puramente negativo. Essas relações não têm força de permanência. Guiado por sua experiência empírica o indivíduo se lança na percepção dos outros em suas diferenças, mas sempre retorna para o si mesmo em sua singularidade. $\mathrm{O}$ indivíduo não se realiza em sua humanidade, pois se há sociabilidade esta não goza de estabilidade e não se alcança verdadeiramente o bem comum. "A vida ética", ao contrário, "com a aniquilação completa da particularidade ...deve ser absoluta identidade da inteligência...a suprassunção da determinidade e configuração naturais...indiferença plena do gozo de si (Selbstgenuss) ... a essência do indivíduo ... é verdadeiramente infinita, pois toda sua determinidade é aniquilada". ${ }^{84}$ Somente a intuição intelectual por meio da vida ética permite ao indivíduo vivo apreender-se no outro permanecendo si mesmo e, por conseguinte, apreender-se "em cada qual como a si mesmo". O indivíduo não está isolado em sua particularidade e nem a impõe sobre os outros indivíduos, por isso "na vida ética o indivíduo é também de um modo eterno, seu ser e agir empíricos é simplesmente universal, pois não é o individual que age, mas o espírito absoluto universal nele. A visão da filosofia acerca do mundo e da necessidade, segundo a qual todas as coisas estão em Deus e nenhuma particularidade existe, é perfeitamente realizada para a consciência empírica na medida em que aquela particularidade do agir ou do pensar ou do ser tem a sua essência e significação tão somente no todo, e na medida em que o seu fundamento pensado (então) é tão somente o todo pensado". ${ }^{85}$ As palavras de Hegel podem soar estranhas aos ouvidos contemporâneos, todavia não devem ser consideradas como mero arcaísmo, um ponto de vista anterior ao processo de secularização da sociedade ocidental. Para ele a totalidade concreta na qual a individualidade encontra a sua maior riqueza e realização é o "Povo" e este não é "a relação de uma multidão de indivíduos, nem uma multidão sem relação, nem mera pluralidade...na medida em que o povo é indiferença vivente (nele)...o particular, o indivíduo enquanto consciência particular é simplesmente igual ao universal e esta universalidade

\footnotetext{
83 “In der vorhergehenden Potenzen ist die Totalität der Besonderheit nach ihren beiden Seiten, der Besonderheit als solcher, und der Allgemeinheit als abstracter Einheit". Sittlichkeit, p. 59. ${ }^{84}$ Cf. "Die Sittlichkeit muss völliger Vernichtung der Besonderheit ...absolute Identität der Intelligenz sein...die Aufhebung der natürlichen Bestimmtheit und Gestaltung, völlige/ Indifferenz des Selbstgenusses ... (das) Wesen des Individuums ...ist wahrhaft unendlich, denn alle seine Bestimmtheit ist vernichtet..." Sittlichkeit, p. 60.

${ }^{85}$ Cf. "In der Sittlichkeit ist also das Individuum auf eine ewige Weise; sein empirisches Sein und Tun ist ein schlechthin allgemeines; denn es ist nicht das Individuelle, welches handelt, sondern der allgemeine absolute Geist in ihm. Die Ansicht der Philosophie von der Welt und der Notwendigkeit, nach welcher alle Dinge in Gott sind, und keine Einzelheit ist, ist für das empirische Bewusstsein vollkommen realisiert, indem jene Einzelheit des Handelns oder Denkens oder Seins ihr Wesen und Bedeutung ganz allein im Ganzen hat, und, insofern ihr Grund gedacht, ganz allein dieses gedacht wird", Sittlichkeit, p. 61.
} 
com a qual a particularidade simplesmente se unificou é a divindade do povo (die Göttlichkeit des Volkes) e este universal intuído na forma ideal da particularidade é o Deus do povo (Gott des Volkes), ele (Deus) é uma maneira ideal de intuí-lo."86

Não se trata de divinização do povo, de considerá-lo como se fosse Deus ou, conforme se mencionou acima, uma espécie de idolatria política, pois o povo considerado em sua realidade histórica e concreta, mas na perspectiva lógica da exposição é também visto enquanto manifestação da vida ética. Ora, esta só pode ser pensada em perspectiva filosófica quando referida a uma instância simultaneamente transcendente ao indivíduo e a qualquer comunidade humana particular, porém, de certa forma, neles age de forma imanente. Hegel não está defendendo uma nova cristandade ao modo do "Ancien Régime", ao contrário, ele combate justamente esse tipo de pretensão por parte do catolicismo, assim como também rejeita a piedade subjetiva e sentimental do pietismo e adota o sentido moderno de uma constituição laica, formal e autônoma. No entanto, se o Estado e a religião são esferas separadas e não podem ser confundidos, contudo o fundamento ético do Estado não pode dispensar no plano "da verdade dos princípios e da disposição do espírito" elementos de caráter metafísico e religioso. ${ }^{87}$

O que está em jogo é a exigência de recorrer a um modo de pensar capaz de ultrapassar os limites da consciência empírica. Nesta a diferença predomina sobre percepção da indiferença, enquanto na intuição intelectual a indiferença suprassume a diferença. A Ideia de povo é apresentada como totalidade orgânica viva e independente das particularidades e se manifesta efetivamente no Estado e no governo como figuras e modos de exteriorização da eticidade. O indivíduo, porém, não se dissolve no Estado considerado em sua existência efetiva, mas nele permanece em sua independência e liberdade, porque a vida ética não é concebida a partir do Estado e sim este a partir da vida ética absoluta a qual não subsiste abstratamente ou em qualquer realidade empírica contingente, pois se faz presente em cada ser-singular enquanto espírito vivo. Por outro lado, "significativamente na definição hegeliana de eticidade, esta é a expressão da ação moral, embora não seja, como ocorre em Kant, oposta à natureza. O sujeito moral

\footnotetext{
${ }^{86}$ Cf. "In dem Volke nämlich ist überhaupt formell die Beziehung einer Menge von Individuen gesetzt, nicht eine beziehungslose Menge, noch eine blosse Mehrheit ...Indem das Volk die lebendige Indifferenz...sondern das Besondere, das Individuum als besonderes Bewusstsein schlechthin dem Allgemeinen gleich; und diese Allgemeinheit, welche die Besonderheit schechthin mit sich vereignit hat, ist die Göttlichkeit des Volkes, und/ dieses Allgemeine in der ideellen Form der Besonderheit angeschaut, ist der Gott des Volkes; er ist eine ideelle Weise es anzuschauen". Sittlichkeit, p. 61-62.

${ }^{87}$ Não podemos nos estender neste ponto. Ver: HEGEL, G.W.F. Linhas fundamentais da filosofia do direito, op. cit. $\S 270$. Ver também: PONTON, Lionel. "Le divin comme préoccupation politique chez Aristote et chez Hegel". In: DE KONINCK, Thomas et PLANTY-BONJOUR, Guy. La question de Dieu selon Aristote et Hegel. Paris: PUF, 1991, p. 207-209.
} 
e a natureza alcançam a unidade numa ordem institucional na qual coincidem liberdade e necessidade, direitos e obrigações" 88

A dificuldade em compreender a concepção hegeliana provém, como já foi dito e vale repetir, da desconsideração do alcance ontológico e/ou metafísico da dialética em seu significado propriamente idealista e da adoção da posição dualista do entendimento (Verstand) que leva à separação entre natureza e cultura e torna incompreensível a passagem de uma à outra. A solução materialista seria ainda menos aceitável do que a do agnosticismo do entendimento, porque nessa perspectiva o "ético", desprovido de sua sustentação no "lógico" (das Logische) acaba sendo vinculado à sua gênese empírica e todas as dimensões do humano passam a depender em última instância do "sistema das necessidades". Desse modo ou acabamos por cair em algum tipo de atomismo individualista ou concebemos abstratamente a totalidade social em detrimento do indivíduo em sua singularidade viva. E o fazemos, em última instância, por estarmos presos nas oposições cristalizadas do entendimento e este "opõe resistência à dialética". O entendimento preso à fixidez de seus conceitos resiste em reconhecer que "todo o finito, em lugar de ser algo firme e último, é antes variável e passageiro; e não é por outra coisa senão pela dialética do finito que ele, enquanto é em si o Outro de si mesmo, é levado também para além do que ele é imediatamente, e converte-se em seu oposto". Por isso, Hegel observa em seguida "no [campo] político, os extremos da anarquia e do despotismo costumam suscitar-se mutuamente um ao outro". 89

\section{III}

Por que abordarmos um manuscrito como o "Sistema de eticidade" se possuímos o sistema completo do filósofo e, sobretudo, já temos acesso ao desenvolvimento maduro de sua filosofia política? Como foi observado na introdução de nosso artigo, à luz da cronologia dos escritos de Iena estabelecida por Kimmerle, não se pode antecipar o pensamento do filósofo em sua forma acabada no manuscrito incompleto do "sistema de eticidade". Por outro lado, a contraposição entre o "jovem" Hegel criativo e inquieto e o "velho" filósofo acomodado na obra consagrada também não se sustenta se levarmos em consideração as aquisições posteriores dos cursos de Berlim. Deveríamos supor com Honneth que as intuições de Iena foram abandonadas no gigantesco esforço lógico da construção sistemática? Ou, ao contrário, os escritos anteriores à obra canônica deveriam ser relegados

\footnotetext{
${ }^{88}$ Cf. COBBEN, Paul. "Sittlichkeit". In: IDEM (Hrsg.). Hegel-Lexicon. Darmstadt: Wissenschaftliche Buchgesellschaft, 2006. p. 408.

${ }^{89}$ HEGEL, G.W.F. Enciclopédia das ciências filosóficas em compêndio. Volume I: A ciência da lógica. Tradução de Paulo Meneses. São Paulo: Edições Loyola, p. 165.
} 
a um interesse secundário e apenas restrito a questões menores de historiografia filosófica? Ora, tanto o artigo sobre o direito natural, quanto o manuscrito versando sobre a eticidade indicam o nexo entre os interesses políticos e religiosos desenvolvidos desde 1798 em Frankfurt e os esboços preparados entre os outonos de 1801-1802 para as lições de lógica, metafísica e filosofia da natureza, ministradas como Privatdozent em Iena. Ao privilegiar a vida ética em seu dinamismo intrínseco o filósofo não só se opõe às cristalizações do entendimento, atribuídas às filosofias da reflexão de Kant e Fichte, mas já antecipa como falsa a imagem de rigidez do sistema ${ }^{90}$. Nem as contradições da vida e nem o fluir dos processos históricos podem ser logicamente estancados. As intensas angústias e tênues expectativas acerca da situação de sua época não cessam e não podem ser elevadas à serenidade do conceito se isso significar a neutralização do tempo. As contradições apenas ganham novas feições e a possibilidade da catástrofe está sempre à espreita. Tal não significa abandonar-se ao historicismo como variante do empirismo dogmático, sempre hostil ao trabalho do pensamento e conformado ao senso comum pressuroso em acusar a filosofia de se enredar em contradições e não provar aquilo que arroga afirmar. ${ }^{91}$ Também não significa entregar-se ao ceticismo, pois os céticos apesar de sua aparente sofisticação argumentativa recaem no mesmo erro do senso comum, pois ambos atribuem a gênese dos conceitos à psicologia empírica e esta "dispersa o espírito em qualidades e não encontra dentre elas nenhum todo.."92 Nos dois casos o ponto fulcral consiste numa rejeição apenas aparentemente oposta, porém complementar: o dogmatismo do senso comum não suporta as contradições da razão e o ceticismo as fixa e em sua fixidez torna-as perenes como testemunhos contra a razão, quando na verdade as contradições são o próprio alimento do pensamento.

Seja como for, o que aqui foi feito não passa de um ainda incipiente exercício de leitura que só poderia encontrar um alcance maior se acompanhado do paciente trabalho de reconstrução do caminho percorrido pelo filósofo em seu período de Iena anterior à publicação da "Fenomenologia do espírito". Mas tal trabalho já foi antes e brilhantemente realizado por pesquisadores de grande competência como se vê, por exemplo, nas obras minuciosas de H.S. Harris ou na síntese de Gilbert Gérard. ${ }^{93}$ De todo modo, como foi

${ }^{90}$ BOURGEOIS, Bernard. Hegel. Biographie. Paris: Calmann-Lévy, 1998, p. 152-176.

${ }^{91}$ HEGEL, G.W.F. (1802). "Wie der Gemeine Menschenverstand die Philosophie nehme, Dargestellt an den Werken des Herrn Krug's". In: HEGEL, G.W.F. Gesammelte Werke. Bd. 4: Jenaer Kritische Schriften. Herausgegeben Von Hartmut Buchner und Otto Pöggeler. Hamburg: Fexix Meiner, 1968. p. 178.

${ }^{92}$ HEGEL, G.W.F. (1802). “Verhältnis des Skepticismus zur Philosophie, Darstellung seiner verschiedenen Modificationen, und Vergleichung des Neuesten mit dem Alten", in: HEGEL, G.W.F. Gesammelte Werke. Bd. 4: Jenaer Kritische Schriften. Herausgegeben Von Hartmut Buchner und Otto Pöggeler. Hamburg: Fexix Meiner, 1968. p. 237.

${ }^{93}$ Ver GÉRARD, Gilbert. Critique et dialectique, op. cit. e também HARRIS, H.S. Hegel's development. toward the sunlight. 1770-1801. Oxford: Clarendon Presse, 1972 e, sobretudo, HARRIS, H.S. Hegel's development. Night thoughts (Iena 1801-1806). Oxford: Clarendon Press, 1983. 
observado em nota anterior não há completa coincidência entre as diversas leituras e cada uma tem as suas próprias pressuposições. Quando um autor passa a fazer parte da tradição intelectual a sua obra determina efeitos hermenêuticos imprevisíveis e esta "história dos efeitos" (Wirkungsgeschichte) produz uma verdadeira errância nos possibilitando falar em verdade dos erros e em efetiva aprendizagem conceitual através dos desvios inerentes à pluralidade e ao conflito das interpretações. Aí reside a fecundidade de uma obra maior do pensamento como a hegeliana. Assim, por exemplo, a interpretação kojeviana da "Fenomenologia do espírito" aparece como equivocada, não somente à luz da Hegelforschung, mas também porque o próprio Kojève "foi perfeitamente consciente de ter radicalizado o pensamento de Hegel" de modo a favorecer de modo dissimulado a sua compreensão do sistema na perspectiva da antropogênese ateísta ${ }^{94}$. De maneira semelhante a Marx, do qual foi atento leitor, ele não cometeu um equívoco involuntário a ser corrigido pela pesquisa acadêmica, porque, como mostra a sua carta de 07 de outubro de 1948, dirigida a Tran-Duc-Thao, não temia em confessar o seu desinteresse por saber precisamente o que Hegel mesmo queria dizer ${ }^{95}$. O seu foi o Hegel revelador do advento eminente do reino da liberdade e do fim da história, num momento no qual a sucessão de acontecimentos catastróficos parecia ainda não desmentir a aparente marcha triunfal do marxismo.

Após a derrota política e ideológica do marxismo a partir do início dos anos noventa, talvez o retorno a Hegel permita enfatizar outro viés, embaralhando as cartas da consciência progressista contemporânea. Como o filósofo afirmou no texto introdutório ao primeiro tomo da "Revista Crítica de Filosofia", a ideia de filosofia subverte a certeza imediata de seu ponto de partida e nesse sentido possui um caráter "esotérico" e acaba por ensejar a perda da evidência proporcionada pelo entendimento finito e, por conseguinte, "em relação ao senso comum o mundo da filosofia em si e por si é um mundo invertido" (eine verkehrte Welt)". ${ }^{96}$

O manuscrito sobre a vida ética certamente nos deixa desconcertados tanto por suas inversões dialéticas, quanto porque, no momento de transição das preocupações políticas e religiosas da juventude em direção ao forjamento do sistema especulativo, nele nos deparamos com a necessidade lógica de se introduzir desde o início a ideia de absoluto. Por isso, a vida ética (Sittlichkeit) deve ser pensada, desde seu ponto de partida e mesmo

\footnotetext{
${ }_{94}$ AUFFRET, Dominique. Alexandre Kojève. La philosophie, l' État, la fin de l' Histoire. Paris: Éditions Grasset et Fasquelle, 1990, p. 16-17.

${ }^{95}$ JARCZYK, Gwendoline e LABARRIÈRE, Pierre-Jean. De Kojève a Hegel. Cent cinquante ans de pensée hégélienne en France. Paris: Albin Michel, 1996, p. 64-66.

${ }^{96}$ HEGEL, G.W.F." Kritisches Journal der Philosophie. Ersten Bandes, Erstes Stück. Einleitung", in: IDEM. Jenaer Kritische Schriften. Herausgegeben von BUCHNER, Hartmut und PÖGGELER, Otto. Gesammelte Werke. Bd. 4. Hamburg: Felix Meiner Verlag, 1968. p. 124-125.
} 
em sua realização imperfeita "segundo a relação" (nach dem Verhältnis), como "absoluta". Alguns elementos conceituais do texto já apontam para os manuscritos imediatamente posteriores. No final de suas lições sobre a "Filosofia real", a filosofia é definida como "ciência absoluta" (absolute Wissenschaft) e o é não por uma apreensão imediata e sim porque o saber apenas se sabe quando reconhece o "devir do ser no outro" e se logicamente acaba por reencontrar a si mesmo, enquanto infinito; tal reencontro no tempo se dá como padecimento finito, como atravessamento do outro, do contrário de si mesmo. ${ }^{97} \mathrm{Em}$ nossa época a universalidade abstrata do capitalismo planetário em sua mais elevada expressão "totalitária" engendra de maneira aparentemente inesperada a particularidade abstrata das reivindicações particulares e fragmentárias e aparentemente estimula a afirmação dos direitos subjetivos em sua máxima intensidade. ${ }^{98}$ Como pensar essa deriva da abstração no tempo? O retorno a Hegel em nosso mundo pretensamente "pós-ideológico", ou seja, após o refluxo político e ideológico do marxismo, parece exigir o enfrentamento da tragédia da modernidade. Esta talvez possa ser discernida no impasse vivido pelas sociedades seculares em proceder à dupla confrontação do em si de nosso inegável ser finito e do para si de nosso desejo do absoluto.

\section{Bibliografia}

ARNDT, Andreas. "Lenin liest Hegel". Hegel-Studien. Beiheft 55. Hamburg: Felix Meiner Verlag, 2001. p. 275-290.

AUFFRET, Dominique. Alexandre Kojève. La philosophie, l' État, la fin de l' Histoire. Paris: Éditions Grasset et Fasquelle, 1990.

BOBBIO, Norberto e BOVERO, Michelangelo. Sociedade e Estado na filosofia política moderna. São Paulo: Editora Brasiliense, 1986.

BOURGEOIS, Bernard. Le droit naturel de Hegel (1802-1803). Commentaire. Paris: J. Vrin, 1986.

${ }^{97}$ HEGEL, G.W.F. “Vorlesungsmanuskript zur Realphilosophie”. Gesammelte Werke. Bd. 8. Hamburg: Felix Meiner Verlag, 1976. p. 286. No manuscrito do ano anterior (1804/05) afirma em sua metafísica: "Diss der absolute Kraislauff des absoluten Geistes. Das sich als sichselbstgleichgefunden hat, schaut sich an als ein solches das sich ungleich ist, das andere seiner selbst ist, es ist unendlich; und diese Unendlichkeit ist es selbst, den das Andere ist das Gegenteil seiner selbst, es ist das sichgleiche, und diss ist der Geist, der so im Ungleichen sich selbst anschaut". Cf. HEGEl, G.W. F." Logik, Metaphysik, Naturphilosophie". Jenaer Systemenwürfe II. Gesammelte Werke. Bd. 7. Hamburg: Felix Meiner, 1971. P. 173-174. Para um comentário sobre esses trechos, ver: TAMINIAUX, Jacques. Naissance de la philosophie hégélienne de l' État. Paris: Payot, 1984. p. 13-19.

${ }^{98}$ Sobre o caráter "totalitário" do capitalismo global, ver: VIOULAC, Jean. La logique totalitaire. Essai sur la crise de l'Occident. Paris: PUF, 2013. 
BOURGEOIS, Bernard. Hegel. Biographie. Paris: Calmann-Lévy, 1998.

CARON, Maxence. Être et identité. Méditation sur la 'Logique' de hegel et sur son essence. Paris: Éditions Du Cerf, 2006.

COBBEN, Paul und alii (Hrsg.). Hegel-Lexikon. Darmstadt: Wissenschftliche Buchgesellschaft, 2006.

DE KONINCK, Thomas et PLANTY-BONJOUR, Guy. La question de Dieu selon Aristote et Hegel. Paris: PUF, 1991.

DENIS, Henri. Logique hégélienne et systèmes économiques. Paris: PUF, 1984.

GÉRARD, Gilbert. Critique et dialectique. L'itinéraire de Hegel à Iéna (1801-1805). Bruxelles: Facultés Universitaires Saint-Louis, 1982.

HEGEL, G.W.F. (1801). "Differenz des Fichteschen und Schellingschen Systems der Philosophie". In: IDEM. Jenaer Kritische Schriften. Gesammelte Werke. Bd. 4. Herausgegeben Von BUCHNER, Hartmut und PÖGGELER, Otto. Hamburg: Felix Meiner Verlag, 1969. p. 1-92.

HEGEL, G.W.F. (1801). “Différence entre les systèmes philosophiques de Fichte et de Schelling". In: HEGEL, G.W.F. Premières publications. Traduction, introduction et notes par Marcel Méry. Paris: Paris: Éditions Ophrys, 1964.

HEGEL, G.W.F." (1802 a) "Kritisches Journal der Philosophie. Ersten Bandes, Erstes Stück. Einleitung". IDEM. Jenaer Kritische Schriften. Gesammelte Werke. Bd. 4. Herausgegeben von BUCHNER, Hartmut und PÖGGELER, Otto. Hamburg: Felix Meiner Verlag, 1968. p. 117-128.

HEGEL, G.W.F. (1802 b). “Wie der Gemeine Menschenverstand die Philosophie nehme, - Dargestellt an den Werken des Herrn Krug's". In: HEGEL, G.W.F. Jenaer Kritische schriften. Gesammelte Werke. Bd. 4. Herausgegeben Von Hartmut Buchner und Otto Pöggeler. Hamburg: Fexix Meiner, 1968. p. 174-187.

HEGEL, G.W.F. (1802 c). “Verhältnis des Skepticismus zur Philosophie, Darstellung seiner verschiedenen Modificationen, und Vergleichung des Neuesten mit dem Alten".In: HEGEL, G.W.F. Jenaer Kritische Schriften. Gesammelte Werke. Bd. 4. Herausgegeben Von Hartmut Buchner und Otto Pöggeler. Hamburg: Fexix Meiner, 1968. p. $197-238$.

HEGEL, G.W.F. (1802-1803 a). “Über die wissenschaftlichen Behandlungsarten des Naturrechts, seine Stelle in der praktischen Philosophie, und sein Verhältnis zu den positive Rechtswissenschaften". In: HEGEL, G.W.F Frühe politische Systeme. Herausgegeben und kommentiert von Gerhard Göhler. Frankfurt/M-Berlin/Wien: Verlag Ullstein, 1974. p. 103-199.

HEGEL, G.W.F. (1802-1803 a) Sobre as maneiras científicas de tratar o direito natural: seu lugar na filosofia prática e sua relação com as ciências positivas do direito. Tradução e apresentação de Agemir Bavaresco e Sérgio B. Christino.São Paulo: Edições Loyola: 2007.

HEGEL, G.W.F. (1802-1803 b). "System der Sittlichkeit". In: HEGEL, G.W.F Frühe politische Systeme. Herausgegeben und kommentiert von Gerhard Göhler. Frankfurt/M-Berlin/Wien: Verlag Ullstein, 1974. p. 13-102.

HEGEL, G.W.F. (1804-1805). “Logik, Metaphysik, Naturphilosophie”. In: HEGEL, G.W.F. Jenaer Systementwürfe II. Gesammelte Werke. Bd. 7. Herausgegeben von 
HORSTMANN Rolf-Peter und TREDE, Johann Heinrich. Hamburg: Felix Meiner Verlag, 1971.

HEGEL, G.W.F. (1805-1806). “Vorlesungsmanuskript zur Realphilosophie: Naturphilosophie und Philosophie des Geistes". In: HEGEL, G;W.F. Jenaer Systementwürfe III. Gesammelte Werke. Bd. 8. Hamburg: Felix Meiner Verlag, 1976.

HEGEL, G.W.F. (1812). Ciência da lógica. 1. Doutrina do ser. Petrópolis: Editora Vozes e Bragança Paulist: Editora Universitária São Francisco, 2016.

HEGEL, G.W. F. (1820-21) Linhas fundamentais da Filosofia do Direito. Tradução Paulo Meneses...[et al.]. São Leopoldo, RS: Editora Unisinos; São Paulo: Edições Loyola, 2010.

HEGEL, G. W. F. (1830). Enciclopédia das ciências filosóficas em compêndio. Volume I: A ciência da lógica. Tradução Paulo de Meneses. São Paulo: edições Loyola, 1995.

HONNETH, Axel. Luta por reconhecimento. A gramática moral dos conflitos sociais. São Paulo: Editora 34, 2003.

ILTING, Karl-Heinz. "La forme logique et systématique de la 'Philosophie Du droit'”. In: WEIL, Eric et alii. Hegel et la philosophie Du Droit. Paris: PUF, 1979.

JANICAUD, Dominique. Hegel et le destin de la Grèce. Paris: J. Vrin, 1975.

JARCZYK, Gwendoline e LABARRIÈRE, Pierre-Jean. De Kojève a Hegel. Cent cinquante ans de pensée hégélienne em France. Paris: Albin Michel, 1996.

JEFFRIES, Stuart. Grande Hotel Abismo. A Escola de Frankfurt e seus personagens. São Paulo: Companhia das Letras, 2018.

JONES, Gareth Stedman. "Retrato de Engels". In: HOBSBAWN, Eric et al. (Org.). História do marxismo I: o marxismo no tempo de Marx. Rio de janeiro: Paz e terra, 1979. P. 377-421.

KIMMERLE, Heinz. "Zur Chronologie von Hegels Jenaer Sschriften”. Hegel-Studien. Bd. 4, 1967. p. 125-176.

KIMMERLE, Heinz. Das Problem der Abgeschlossenheit des denkens. Hegels "System der Philosophie" in den Jahren 1800-1804 (Hegel-Studien, Beiheft 8). Bonn: Bouvier Verlag, 1982.

KORSCH, Karl. Marxismo e filosofia. Porto: Edições Afontamento, 1977.

LARDIC, Jean-Marie. L' infini et sa logique. Étude sur Hegel. Paris: Éditions L' Harmattan, 1995.

LÉCRIVAIN, André. Hegel et l'éthicité. Commentaire de la troisième partie des "Principes de la philosophie Du droit". Paris: J. Vrin, 2001.

LÊNIN, Vladimir Ilitch. Cadernos filosóficos: Hegel. São Paulo: Boitempo, 2018.

MAESSCHALCK, Marc. Droit et creation social chez Fichte. Une philosophie moderne de l'action politique. Louvain- Paris: Éditions Peeters, 1996.

MARX, Karl. “Zur Kritik der Hegelschen Rechtsphilosophie”. In: MARX, Karl und ENGELS, Friedrich. Werke. Bd. 1. Berlin: Dietz Verlag, 1964. p. 201-333 
MARX, Karl. Crítica da filosofia do direito de Hegel. Tradução Rubens Enderle e Leonardo de Deus. São Paulo: Boitempo Editorial, 2010.

MENKE, Christoph. Estética y negatividad. Buenos Aires: Fondo de Cultura Económica, 2011.

MERCIER-JOSA, Solange. "Combat pour la reconnaissance et criminalité". In: HENRICH, Dieter und HORSTMANN, Rolf-Peter (hg). Hegels Philosophie des Rechts. Die Theorie der Rechtsformen und ihre Logik. Stuttgart: Klett-Cotta, 1982. p. 75-93.

OTTMANN, Henning. Individuum und Gemeinschaft bei Hegel. Bd. I: Hegel im Spiegel der Interpretationen. Berlin-New York,: Walter de Gruyter: 1977.

PIRES, Edmundo Balsemão. Povo, eticidade e razão. Contributos para o estudo da filosofia política de Hegel. Vols. I e II. Lisboa: Imprensa-Nacional-Casa da Moeda, 2006.

PLANTY-BONJOUR, Guy. Le projet hégélien. Paris: J. Vrin, 1993.

PUNTEL, L. Bruno. “ A ‘Ciência da lógica' deHegel e a Dialética Materialista: uma nova visão de um antigo problema”. Síntese, v.II, n. 5 (outubro-dezembro, 1975): 3-36.

REICH, Evânia Elizete. O reconhecimento em Hegel. Dissertação de Mestrado, UFSC, 2012, https://repositorio.ufsc.br/xmlui/bitstream/handle/123456789/100571/308044. pdf? sequence $=1 \&$ isAllowed $=y$

ROSAS, João Cardoso, GONZÁLEZ, Iñigo e THALER, Mathias. "Filosofia política". In: GALVÃO, Pedro. Filosofia: uma introdução por disciplinas. Lisboa: Edições 70, 2013.

ROSENFIELD, Denis L. Política e liberdade em Hegel.São Paulo: Brasiliense, 1983.

ROSSI, Mario. La génesis Del materialismo histórico. 1. La isquierda hegeliana. Madrid: Alberto Corazón Editor, 1971.

SALVADORI, Massimo L. "Kautsky entre ortodoxia e revisionismo". In: HOBSBAWM, Eric et al. (Org.) História do marxismo II: o marxismo na época da Segunda Internacional. Rio de janeiro: Paz e terra, 1982. p. 299-339.

SANTOS, José Henrique. Trabalho e riqueza na 'Fenomenologia do Espírito' de Hegel. São Paulo: Edições Loyola, 1993.

SANTOS, José Henrique. O trabalho do negativo. Ensaios sobre a 'Fenomenologia do Espírito'. São Paulo: edições Loyola, 2007.

TAMINIAUX, Jacques. La nostalgie de la Grèce a l'aube de l'Idealisme Allemand. La Haye: Martinus Nijhoff: 1967.

TAMINIAUX, Jacques. Naissance de la philosophie hégélienne de l'État. Commentaire et traduction de la Realphilosophie d'Iéna. Paris: Payot, 1984.

THIBODEAU, Martin. Hegel e a tragédia grega. Tradução: Bavaresco, Agemir e Costa, Danilo Vaz-Curado. São Paulo: É Realizações, 2015.

TRAVERSO, Enio. Melancolia de esquerda: marxismo, história e memória. Belo Horizonte: Editora Âyiné, 2018.

VAZ, Henrique C. de Lima. “Recensão de 'G.W.F. Hegel. Vorlesungen über Rechtsphilosophie (1819-1931). Edition und Kommentar von Karl-Heinz Ilting'”. Síntese, v. II, n. 4, p. 19-24, julho-setembro 1975. 
VAZ, Henrique C. de Lima. “Recensão de: Dominique Janicud. Hegel et Le destin de la Grèce". Síntese, v. III, n. 6, p. 116-120, janeiro-março 1976.

VAZ, Henrique C. de Lima. "Sociedade Civil e Estado em Hegel". Síntese, v. VII, n. 19, p. 21-29, maio-agosto 1980.

VAZ, Henrique C. de Lima. "Nota bibliográfica: a filosofia política de Hegel". Síntese, v. VIII, n. 22, p. 113-122, maio-agosto 1981.

VAZ, Henrique C. de Lima. Escritos de filosofia II. Ética e cultura. São Paulo: Edições Loyola, 1988.

VIEILLARD-BARON, Jean-Louis. Hegel. Système et structures théologiques. Paris: Les Éditions du Cerf, 2006.

VIOULAC, Jean. La logique totalitaire. Essai sur la crise de l' Occident. Paris: PUF, 2013.

WOOD, Allen W. "Hegel e o marxismo". In: BEISER, Frederick C. Hegel. São Paulo: Ideias \& Letras, 2014. p. 481-515.

BOURGEOIS, Bernard. Le droit naturel de Hegel (1802-1803). Commentaire. Paris: J. Vrin, 1986.

BOURGEOIS, Bernard. Hegel. Biographie. Paris: Calmann-Lévy, 1998.

Endereço dos Autores:

Carlos Roberto Drawin

Rua Congonhas, 161

Bairro São Pedro

30330-016 Belo Horizonte - MG

carlosdrawin@yahoo.com.br 